\title{
Continued Development of the Rotary Combustor for Refiring Pulverized Coal Boilers
}

\author{
Final Report \\ Contract No: DE-AC26-98FT40337 \\ November 2000 \\ Performance period $14^{\text {th }}$ May 1998 - 30 June 2000 \\ Spinheat, Ltd. \\ 1222 Bronson Road \\ Fairfield, CT 06430 \\ 203 259-6101 \\ Michael J. Virr \\ President \\ CONSOL Energy \\ 4000 Brownsville Road \\ South Park, PA 15129 \\ $412854-6600$ \\ Simon P. Hanson \\ Sr. Research Engineer
}

This project was funded in part by the National Energy Technology Laboratory of the Department of Energy, the Ohio Coal Development Office, Department of Development, State of Ohio, CONSOL Energy and Spinheat Ltd.

This report does not contain Trade Secret/Proprietary Information. 


\section{Disclaimer}

This report was prepared by Murray F. Abbott, JamalB. Mereb and Simon P. Hanson, CONSOL Inc., and Michael J. Virr, Spinheat, Ltd., with support in part by a grant from the DOE and Ohio Coal Development Office/Ohio Department of Development (OCDO/ODOD).

This report was prepared as an account of work sponsored by an agency of the United States Government. Neither the United States Government nor any agency thereof, nor any of their employees, makes any warranty, express or implied, or assumes any legal liability or responsibility for the accuracy, completeness, or usefulness of any information, apparatus, product, or process disclosed, or represents that's its use would not infringe privately owned rights. Reference herein to any specific commercial product, process, or service by trade name, trademark, manufacturer, or otherwise does not necessarily constitute or imply its endorsement, recommendation, or favoring by the United States Government or any agency thereof. The views and opinions of authors expressed herein do not necessarily state or reflect those of the United States Government or any agency thereof.

NOTICE TO JOURNALISTS AND PUBLISHERS: Please feel free to quote and borrow from this report; however, please include a statement noting the DOE and Ohio Coal Development Office's support for the project. 


\section{$\underline{\text { Report Summary }}$}

The Rotary Combustor is a novel concept for burning coal with low $\mathrm{SO}_{2}$ and $\mathrm{NO}_{\mathrm{x}}$ emissions. It burns crushed coal in a fluid bed where the bed is maintained in a rotating drum by centripetal force. Since this force may be varied, the combustor may be very compact, and thus be a direct replacement for a p.c. burner on existing boilers.

The primary objective of this project is to demonstrate that a typical industrial boiler can be refired with the modified prototype Rotary Combustor to burn Ohio high-sulfur coal with low emissions of $\mathrm{SO}_{2}$ and $\mathrm{NO}_{\mathrm{x}}$. The primary problem that must be resolved to demonstrate sustained operations with coal is temperature control in the rotating fluid bed.

The prototype Rotary Combustor was assembled and installed on the T-850P CNB boiler at the CONSOL Energy site in South Park, Pennsylvania. Several design improvements were investigated and implemented during the assembly to improve the prototype Rotary Combustor operations compared to prior tests at Detroit Stoker in Monroe, Michigan. An Operating Manual and Safety Review were completed.

The shakedown test phase was initiated. Two major problems were initially encountered: binding of the rotating drum at operating temperatures, and reduced fluid-bed pressure drop after short periods of operation. Plating the brush seal rotary land ring with a chrome carbide plasma spray and lubricating the seal prior to each test sufficiently resolved these problems to permit a limited number of operations tests.

Unlike previous tests at Detroit Stoker, sustained operation of the prototype Rotary Combustor was accomplished burning a high-Btu fuel, metallurgical coke. The prototype Rotary Combustor was operated with coke in gasifier mode on two occasions. Fluid-bed temperature spiking was minimized with manual control of the feeds (coke, air and steam), and no clinker formation problems were encountered in either test. Emission levels of NOx were measured at about 270 ppmv which were higher those targeted for the device which were 100 ppmv. This was assumed to be because of the aforementioned temperature spiking.

The primary operating problem remains control of the fluid-bed temperature. Although improvements were made, steam flow control was manual, and very coarse. To accomplish this will require finer control of the steam flow to the rotary drum air plenum, and development of an algorithm for automatic control using the Moore APACS ${ }^{\mathrm{TM}}$. This is the recommended succeeding step in the development of the Rotary Combustor for industrial or utility use. 


\section{$\underline{\text { Table of Contents }}$}

Page No.

Disclaimer

Report Summary $\quad$ ii

Table of Contents $\quad$ iii

List of Drawings $\quad$ V

List of Photographs $\quad$ V

$\begin{array}{ll}\text { Executive Summary } & 1\end{array}$

$\begin{array}{ll}\text { Report } & 3\end{array}$

$\begin{array}{ll}1.0 \text { Introduction } & 3\end{array}$

1.1 Problem Statement $\quad 3$

$\begin{array}{ll}1.2 \text { Objectives } & 3\end{array}$

1.3 Project Sponsors 3

2.0 Technical Discussion $\quad 4$

2.1 Description of the Rotary Combustor 4

2.1.1 $\mathrm{SO}_{2}$ Control 4

2.1.2 $\mathrm{NO}_{\mathrm{x}}$ Control 5

2.1.3 Particulate Emissions Control 5

2.2 Prototype Rotary Combustor 5

2.3 Redesign of Rotary Combustor Before Installation at CONSOL 7

2.3.1 Distributor Optimization $\quad 7$

2.3.2 Rotary Fin Optimization 10

2.3.3 Other Modifications 13

2.4 Rotary Combustor Installation on CONSOL T-850P CNB Boiler 14

2.5 Rotary Combustor Test Program 17

2.5.1 Shakedown Test Results 18

2.5.2 Operations Test Results 21

2.5.3 Summary of Operating Problems 26

2.5.4 Summary of Accomplishments $\quad 27$

3. 0 Market i ng/ Commerci al i zat i on Di scussi on 29

$\begin{array}{ll}\text { 4.0 Final Budget Summation } & 30\end{array}$

Appendix A

Operating Manual

\section{Drawings}




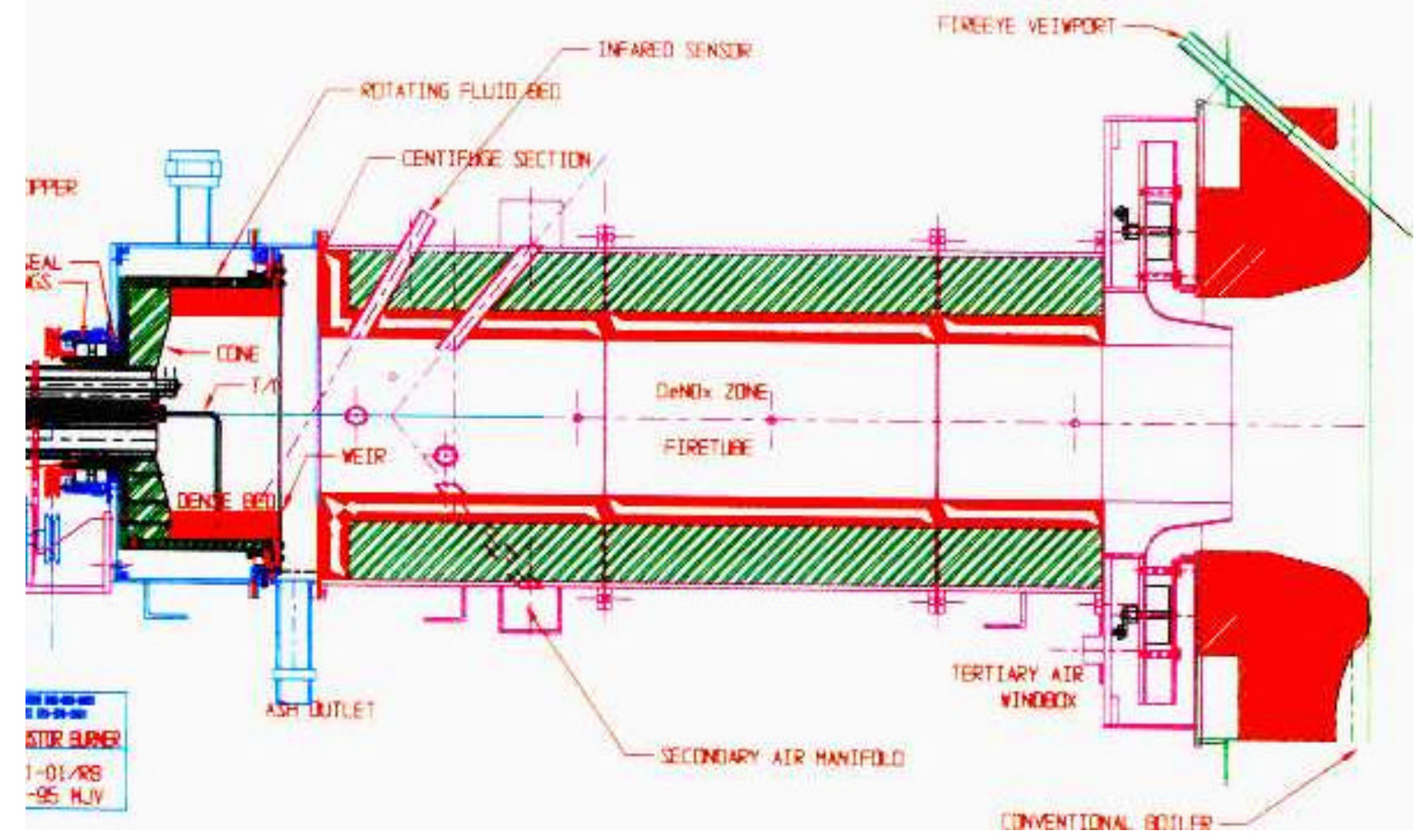

Drawing No: 1 Rotary Combustor Burner 


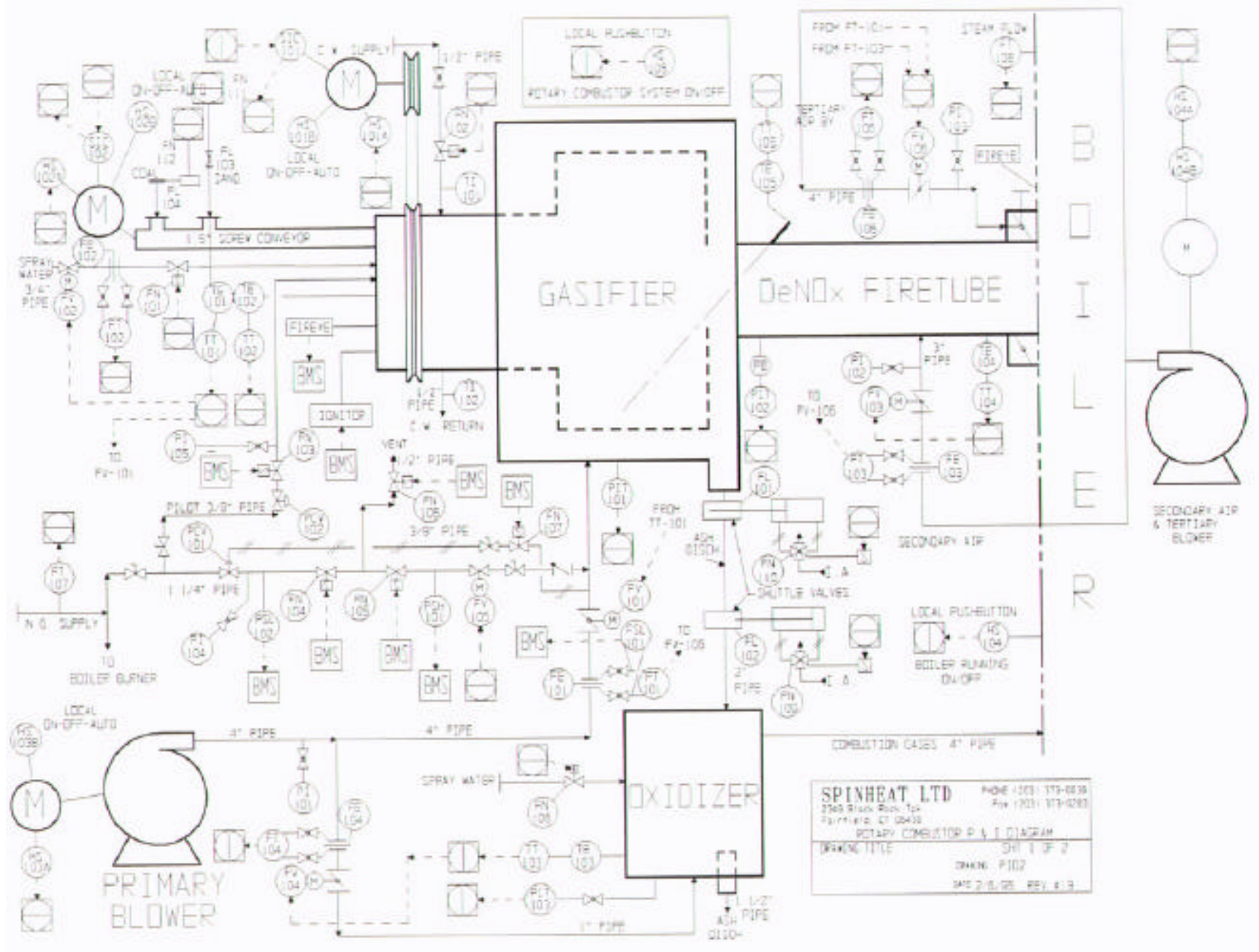

Drawing No: 2. Pipework and Instrument Diagram Revision \#19 


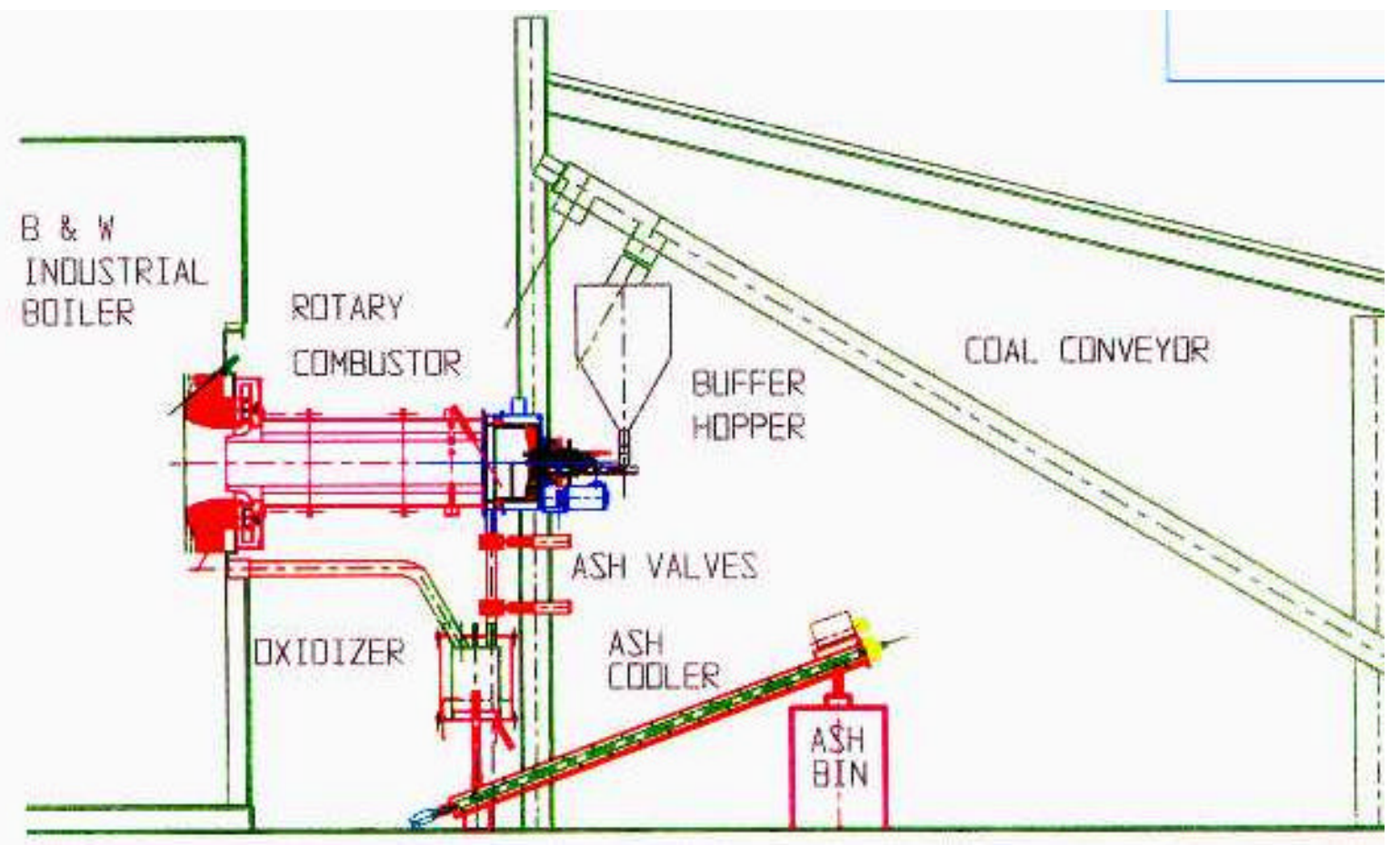

Drawing No: 3 Rotary Combustor Boiler Room Layout 


\section{$\underline{\text { List of Drawings }}$}

$\underline{\text { Page No. }}$

Drawing No. 1 - Rotary Combustor Burner

Drawing No. 2 - Rotary Combustor P\&ID Diagram

Drawing No. 3 - Rotary Combustor Boiler Room Layout

\section{List of Photographs}

$\underline{\text { Page No. }}$

Photograph No. 1 - Plastic and metal one-third-scale cold-flow model.

Photograph No. 2 - Detail of flow test using two colors of sand and distribution fins.

Photograph No. 3 - Flow test on model demonstrating good distribution.

Photograph No. 4 - Distribution fins outside of coal conveying screw.

Photograph No. 5 - Rotary Combustor mounted on CNB T850-P boiler at the CONSOL Energy South Park site.

Photograph No. 6 - Primary and secondary air flow fans with control valves and flow measurement devices alongside the CNB boiler.

Photograph No. 7 - Pratt \& Whitney brush seal mounted in stator.

Photograph No. 8 - Galling of rotor by brush seal.

Photograph No. 9 - Rotary Combustor flame with no tertiary air.

Photograph No. 10 - Rotary Combustor flame with tertiary air on.

\section{$\underline{\text { List of Tables }}$}

$\underline{\text { Page No. }}$

Table No. 1 - Emissions Summary

Table No. 2 - Summary of Accomplishments

Table No. 3 - Rotary Combustor Test Schedule and Objectives

Table No. 4 - Rotary Combustor Mechanical Problems

Table No. 5 - Emissions Summary

Table No. 6 - Summary of Accomplishments 


\section{Executive Summary}

The Rotary Combustor is a novel concept for burning coal with low $\mathrm{SO}_{2}$ and $\mathrm{NO}_{\mathrm{x}}$ emissions. It burns crushed coal in a fluid bed where the bed is maintained in a rotating drum by centripetal force. Since this force may be varied, this enables the combustor to be very compact and arranged in a similar configuration to a conventional burner, and thus be a direct replacement for a p.c. burner on existing boilers.

The primary objective of this project is to demonstrate that a typical industrial boiler can be refired with the modified prototype Rotary Combustor to burn Ohio high-sulfur coal with low emissions of $\mathrm{SO}_{2}$ and $\mathrm{NO}_{\mathrm{x}}$. Specific project objectives are to demonstrate sulfur reduction of $90 \%, \mathrm{NO}_{\mathrm{x}}$ emissions of the order of $100 \mathrm{ppm}$, and continuous operation of twoweeks duration burning Ohio high-sulfur coal. The primary problem that must be resolved to demonstrate sustained operations with coal is temperature control in the rotating fluid bed.

The prototype Rotary Combustor was assembled and installed on the T-850P CNB boiler at the CONSOL Energy site in South Park, Pennsylvania. Several design improvements were investigated and implemented during the assembly to improve Rotary Combustor operations: 1. Distributor was redesigned to improve radial distribution and mixing in the bed; 2 . Radial fins were added to the back plate of the rotary drum to improve penetration of the incoming feed into the dense fluid bed and prevent bed carryover; 3 . The existing disc seal at the hightemperature end of the rotary drum was replaced with a brush seal from Pratt and Whitney; 4. The spool piece connecting the rotary drum and the $\mathrm{DeNO}_{\mathrm{x}}$ Firetube was increased by 3", and the ash discharge pipe and shuttle valve assembly to the Oxidizer also was increased to 3" ID to avoid plugging problems with ash clinkers; and 5. The pilot burner was repositioned in the $\mathrm{DeNO}_{\mathrm{x}}$ Firetube to facilitate start-up of the rotary drum burning natural gas.

An Operating Manual and Safety Review were completed. The Operating Manual and the R\&D Safety Checklist for the Rotary Combustor Installation on the T-850P CNB Boiler is included in Appendix A.

The shakedown test phase was initiated. Two major problems were initially encountered: binding of the rotating drum at operating temperatures, and reduced fluid-bed pressure drop after short periods of operation. Plating the brush seal rotary land ring with a chrome carbide plasma spray, and lubricating the seal prior to each test sufficiently resolved these problems to permit a small number of operations tests.

Unlike previous tests at Detroit Stoker, sustained operation of the prototype Rotary Combustor was accomplished burning a high-Btu fuel, metallurgical coke. The prototype Rotary Combustor was operated with coke in gasifier mode on two occasions. Fluid-bed temperature spiking was minimized with manual control of the feeds (coke, air and steam), and no clinker formation problems were encountered in either test. 
A summary of emissions levels for the final tests in April and June is given in the table below. All reported emissions levels are corrected to $4 \%$ excess oxygen. The $\mathrm{SO}_{2}$ emissions objective is not demonstrated because limestone was not added to the bed for the short duration tests. The $\mathrm{NO}_{\mathrm{x}}$ emissions objective is not demonstrated for a sustained test, although the low end of the results reported for the June 8 test is slightly below $100 \mathrm{ppm}$.

Table No. 1: Emissions Summary

\begin{tabular}{||l|l|r|r|r|r||}
\hline Test Date & Operating Condition & $\begin{array}{c}\text { CO, } \\
\text { ppmv }\end{array}$ & $\begin{array}{c}\mathbf{N O}_{\mathbf{x}}, \\
\mathbf{p p m v}\end{array}$ & $\begin{array}{c}\mathbf{N O}_{\mathbf{x}}, \\
\text { lb/MM Btu }\end{array}$ & \multicolumn{1}{c|}{$\begin{array}{c}\mathbf{S O}_{\mathbf{2}}, \\
\text { ppmv }\end{array}$} \\
\hline April 6 & Gasifier - w/o tertiary air & $435-5,038$ & $\sim 200$ & $\sim 0.28$ & $250-342$ \\
\hline June 8 & Gasifier - with tertiary air & na & $90-271$ & $0.13-0.38$ & $67-270$ \\
\hline
\end{tabular}

The table below summarizes the accomplishments of the Rotary Combustor testing on the CONSOL Energy T-850P CNB boiler. The two principal accomplishments are sustained operation burning a high-Btu fuel, and operation in the gasifier mode. The concept of using steam injection with the plenum air for temperature control in the fluid bed is demonstrated.

Table No. 2: Summary of Accomplishments

\begin{tabular}{||l|l||}
\hline \multicolumn{1}{||c|}{ Demonstrated } & \multicolumn{1}{c|}{ Not Demonstrated } \\
\hline Sustained operation burning a high-Btu solid fuel (coke) & Fine/automatic temperature control \\
\hline Steam injection/gasifier mode & Very low $\mathrm{NO}_{\mathrm{x}}$ emissions \\
\hline \hline
\end{tabular}

The primary operating problem remains control of the fluid-bed temperature. Although improvements were made, steam flow control was manual, and very coarse. To accomplish this will require finer control of the steam flow to the rotary drum air plenum, and development of an algorithm for automatic control using the Moore APACS ${ }^{\mathrm{TM}}$. This is the recommended next step in the development of the Rotary Combustor for industrial use. At that time, the emissions objectives can be tested. 


\section{$\underline{\text { Report }}$}

\subsection{Introduction}

\subsection{Problem Statement}

A prototype Rotary Combustor was previously fabricated and tested under a U. S. Department of Energy SBIR grant (No. DE-FG05-93ER81515). Coal burning tests did not give sustainable operation due to temperature instabilities and clinker formation in the Rotary Combustor drum. Another problem was carryover of fuel from the drum due to poor penetration of the coal into the dense fluid bed.

\subsection{Objectives}

The overall objective is to demonstrate that a typical industrial boiler can be refired with the modified prototype Rotary Combustor to burn Ohio high-sulfur coal with low emissions of $\mathrm{SO}_{2}$ and $\mathrm{NO}_{\mathrm{x}}$.

Specific project objectives are to demonstrate sulfur reduction of $90 \%, \mathrm{NO}_{\mathrm{x}}$ emissions of the order of $100 \mathrm{ppm}$, and continuous operation of two-weeks duration burning Ohio high-sulfur coal.

\subsection{Project Sponsors}

The project sponsors include the OCDO, the United States Department of Energy, CONSOL Inc., and Spinheat, Ltd. CONSOL is the largest producer of high-Btu bituminous coal in the United States, and from 1986 to 1999, produced between 2 million and 5 million tons of coal annually from the Pittsburgh seam at the Pocahontas mine in Belmont County, Ohio. Spinheat, Ltd. is the inventor of the Rotary Combustor technology (US Patents \#5,070,821 and \#5,390,630) and owner of the prototype. The OCDO and the US DOE each contributed $\$ 143,035$, and CONSOL and Spinheat respectively contributed $\$ 85,000$ and $\$ 58,035$ of the total $\$ 429,105$ project cost. 


\subsection{Technical Discussion}

\subsection{Description of the Rotary Combustor}

The Rotary Combustor is a novel concept for burning coal with low $\mathrm{SO}_{2}$ and $\mathrm{NO}_{\mathrm{x}}$ emissions. It burns crushed coal in a fluid bed where the bed is maintained in a rotating drum by centripetal force. Since this force may be varied, this enables the combustor to be very compact and arranged in a similar configuration to a conventional burner, and thus be a direct replacement for a p.c. burner on existing boilers.

The first process stage in the Rotary Combustor is a rotating drum into which fuel and limestone are fed and thrown to the inside surface of the drum. The drum supports a porous distributor plate, and the fuel and limestone particles are suspended in the stream of air that flows through the distributor plate. Since the fuel and limestone are being thrown outward, the air is introduced through the distributor plate with a comparable inward force. This force can be varied to levels much higher than gravitational forces. The result of the high centripetal force is a dense fluid bed around the inner circumference of the drum. This permits a greater combustion intensity that the conventional fluid-bed combustor, which allows the unit to be much smaller in size.

The Rotary Combustor drum is operated with less than the full complement of combustion air flow, which forms a low-Btu syngas from partial combustion of the coal. The resultant syngas exits the rotating drum and flows into the second process stage $\mathrm{DeNO}_{\mathrm{x}}$ Firetube where its temperature is increased by injecting secondary air. The rise in temperature dissociates the $\mathrm{NO}_{\mathrm{x}}$ precursors into nitrogen and water vapor before the syngas combustion is completed downstream in the main burner flame. Finally, in the third process stage the hightemperature syngas exits the $\mathrm{DeNO}_{\mathrm{x}}$ Firetube and enters the boiler furnace where tertiary air is added to complete combustion. The flame is similar to a natural gas flame, with the exception of a low concentration of radiating fly ash particles. The coal sulfur is mostly absorbed by the limestone in the rotary drum, and the fuel-nitrogen is predominantly fixed as molecular nitrogen in the $\mathrm{DeNO}_{\mathrm{x}}$ Firetube.

\subsection{1 $\underline{\mathrm{SO}}_{2} \underline{\text { Control }}$}

The sulfur in the coal is absorbed in the traditional manner used in fluid beds. Limestone is fed with the coal through the feed screw. It calcines to the oxide form in the fluid bed, which is controlled at the optimum temperature range, $1600^{\circ} \mathrm{F}$ to $1650^{\circ} \mathrm{F}$. Calcium oxide reacts with the gaseous sulfur species released from the coal to form calcium sulfide, since the atmosphere in the drum is predominantly reducing in nature. The calcium sulfide particles, together with the residual coal ash, spill over the weir at the end of the spinning drum and into the ash hopper. The solids then pass through a lock hopper system into the Oxidizer, a conventional fluid bed, where the calcium sulfide is converted to sulfate form and the residual carbon is burned. In this manner, greater than $90 \%$ of the coal sulfur is removed from the syngas before combustion is completed in the $\mathrm{DeNO}_{\mathrm{x}}$ Firetube and boiler furnace. The hot Oxidizer flue gas is returned to the boiler furnace so no heat is lost. 


\subsection{2 $\underline{\mathrm{NO}_{x}}$ Control}

The $\mathrm{NO}_{\mathrm{x}}$ emission is controlled by the two-stage rotary drum gasifier and $\mathrm{DeNO}_{\mathrm{x}}$ Firetube arrangement. The fuel nitrogen is the only nitrogen component in the Rotary Combustor input streams that can form $\mathrm{NO}_{\mathrm{x}}$ precursors under the conditions in the rotary drum. Under the gasification conditions in the drum, the nitrogen in the coal will tend to form ammonia $\left(\mathrm{NH}_{3}\right)$ and some hydrocyanic acid $(\mathrm{HCN})$. In the DeNO ${ }_{x}$ Firetube, where temperatures exceed $3000^{\circ} \mathrm{F}$ and oxygen concentrations remain low, these products dissociate into nitrogen and water vapor. The fuel nitrogen is fixed as molecular nitrogen before final combustion in the boiler furnace. Target $\mathrm{NO}_{\mathrm{x}}$ emissions are of the order of $100 \mathrm{ppm}$. In the previous SBIR project, computational fluid dynamics modeling demonstrated the feasibility of this $\mathrm{NO}_{\mathrm{x}}$ control technique. Additionally, since the final combustion temperature exceeds $2000 \mathrm{~F}$, the formation of $\mathrm{NO}_{2}$ is inhibited and should be less than $10 \mathrm{ppm}$, compared to $100 \mathrm{ppm}$ levels produced by conventional fluid bed combustors.

\subsubsection{Particualte Emissions Control}

The coal ash is predominantly removed at the end of the rotary drum, prior to the $\mathrm{DeNO}_{\mathrm{x}}$ Firetube and the boiler furnace. This provides some measure of particulate control and reduces exposure of the boiler heat transfer surfaces to slagging, fouling and hightemperature corrosion. However, there is sufficient fly ash particle loading exiting the Rotary Combustor to give radiant heat transfer to the boiler furnace water-wall tubes. Unlike natural gas burners, this permits retrofit of the Rotary Combustor into a coal-fired boiler with little or no loss in furnace heat absorption. Final particulate control can be accomplished with a baghouse. The combined Oxidizer ash and baghouse ash will be no different to that produced by a Circulating Fluid Bed system, and should not present any unusual disposal problem. In fact, the products may be desirable for cement or road base materials.

\subsection{Prototype Rotary Combustor}

In 1993, Detroit Stoker Company and Spinheat, Ltd. personnel fabricated a prototype Rotary Combustor at the Detroit Stoker Company facilities in Monroe, Michigan. The prototype was mounted on a Babcock and Wilcox test boiler at the same location. The first tests of the prototype were conducted at this facility under a SBIR Phase II grant secured by Spinheat, Ltd. These tests were only partially successful.

The prototype was operated continuously for several days on refuse-derived fuel (RDF) pellets (mostly compressed paper). However, when fired with high-Btu bituminous coal, the prototype operation was never sustainable for more than two hours because of poor temperature control and clinkering in the rotating fluid bed. Other problems also were observed when burning coal. There was evidence that the larger coal particles ( ") were skipping across the top of and bypassing the fluid bed. Also, the disc seal used to seal the rotating drum and the air plenum at the hot end of the reactor exhibited a very short lifetime before leaking, and severely restricting test conditions. 
The results of this work are reported in detail in the final report to the U. S. Department of Energy, entitled "Development of a Rotary Combustor for Pulverized Coal Boilers" under Contract No. DE-FG05-93ER81515. 


\subsection{Redesign of Rotary Combustor Prior to Installation at CONSOL}

Modification of the Rotary Combustor constitutes the first task of a three-task work scope for the current project at the CONSOL Energy site in South Park, Pennsylvania. The other two tasks are the Rotary Combustor Installation on the CONSOL T-850P CNB Boiler and the Rotary Combustor Test Program. All three tasks are discussed below according to task, objectives and accomplishments.

The objective of this task is to modify the rotary combustor to eliminate imperfect fluid bed operation, observed during earlier tests, caused by clinker formation and coal bypassing. These problems are due to inadequate mixing in parts of the fluid bed, and poor integration of the coal feed in the bed material. A redesigned air distributor plate, to better mix the bed material, and a solid feed system that impels the coal into the bed, to integrate the coal quickly with the bed material, is required. These and other design improvements were implemented during the installation phase of the project.

The design improvements investigated and implemented during the assembly to improve Rotary Combustor operations include: 1. Distributor was redesigned to improve radial distribution and mixing in the bed; 2 . Radial fins were added to the back plate of the rotary drum to improve penetration of the incoming feed into the dense fluid bed and prevent bed carryover; 3 . The existing disc seal at the high-temperature end of the rotary drum was replaced with a brush seal from Pratt and Whitney; 4 . The spool piece connecting the rotary drum and the $\mathrm{DeNO}_{\mathrm{x}}$ Firetube was increased by 3", and the ash discharge pipe and shuttle valve assembly to the Oxidizer also was increased to 3" ID to avoid plugging problems with ash clinkers; and 5. The pilot burner was repositioned in the $\mathrm{DeNO}_{\mathrm{x}}$ Firetube to facilitate start-up of the rotary drum burning natural gas.

The distributor and radial fin design improvements were investigated at Spinheat, Ltd. using a cold flow model test facility prior to their implementation during reassembly of the Rotary Combustor and installation at CONSOL.

\subsubsection{Distributor Optimization}

A new composite distributor was made up and fitted to the Rotary Combustor cold flow model. It consists of a drilled plate of $4.77 \%$ free area and a backing of finely woven mesh (to prevent sifting in the fluid bed) of Duropore grade 407570. The cold flow model, originally designed and fabricated under the Spinheat, Ltd. SBIR-I grant, is a one-third-scale model made of machined aluminum and Plexiglas. It has an 8 " diameter bed and will support a 1.5" deep fluid bed. The cold flow model and associated strobe light are shown in Photograph No. 1 at the top of the next page. 


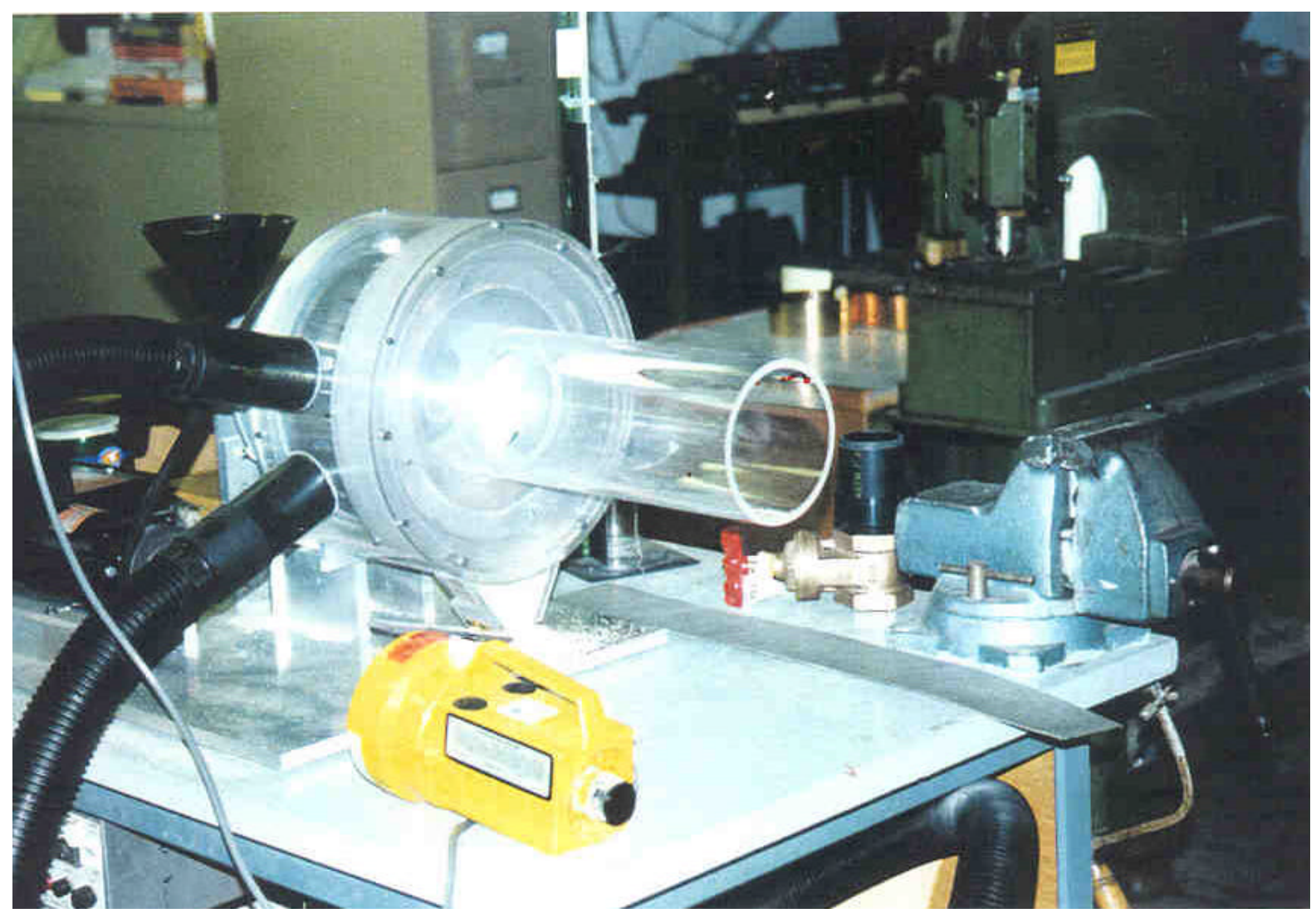

Photograph No. 1 - Plastic and metal one-third-scale cold-flow model.

The cold flow model can be rotated at speeds equivalent to $5 \mathrm{Gs}$ to $15 \mathrm{Gs}$, and blown with cold air at up to $10 \mathrm{ft} / \mathrm{sec}$ velocity. The full-size Rotary Combustor is designed to fluidize at a maximum of about $9.8 \mathrm{ft} / \mathrm{sec}$ hot air velocity and $10 \mathrm{G}$ rotational velocity.

The new composite distributor is different from the one used in the final SBIR-II tests. It was a single finely woven mesh of Durapore grade 401430, which exhibited a pressure drop (dP) of 2.7" WC at the design point. The new composite distributor (containing the Dynapore grade 407570 mesh) is designed for a similar pressure drop but with individual high velocity jets into the bed, which should introduce more bed "stirring" in an effort to prevent clinker formation. A drawing of this new composite distributor is shown in Drawing No. DOE3-1003/R0..

The new composite distributor was first tested for its pressure drop characteristic against superficial velocity without bed material at $10 \mathrm{G}$ rotational speed, as verified using the strobe light. The pressure drop characteristic of the new composite distributor is similar to the previous distributor plate. The measured $\mathrm{dP}$ was actually slightly lower. These test results are displayed in Graph No. 1.

Two colors of sand were then added to the cold flow model as bed material. First, dark-color sand was added to give a bed of approximately $1 / 2 "$. The remaining bed thickness (defined 
by the weir height) was filled with light-color sand (while rotating the drum to keep the two sand layers in place). The object of using the two distinct colors of sand was to assess the

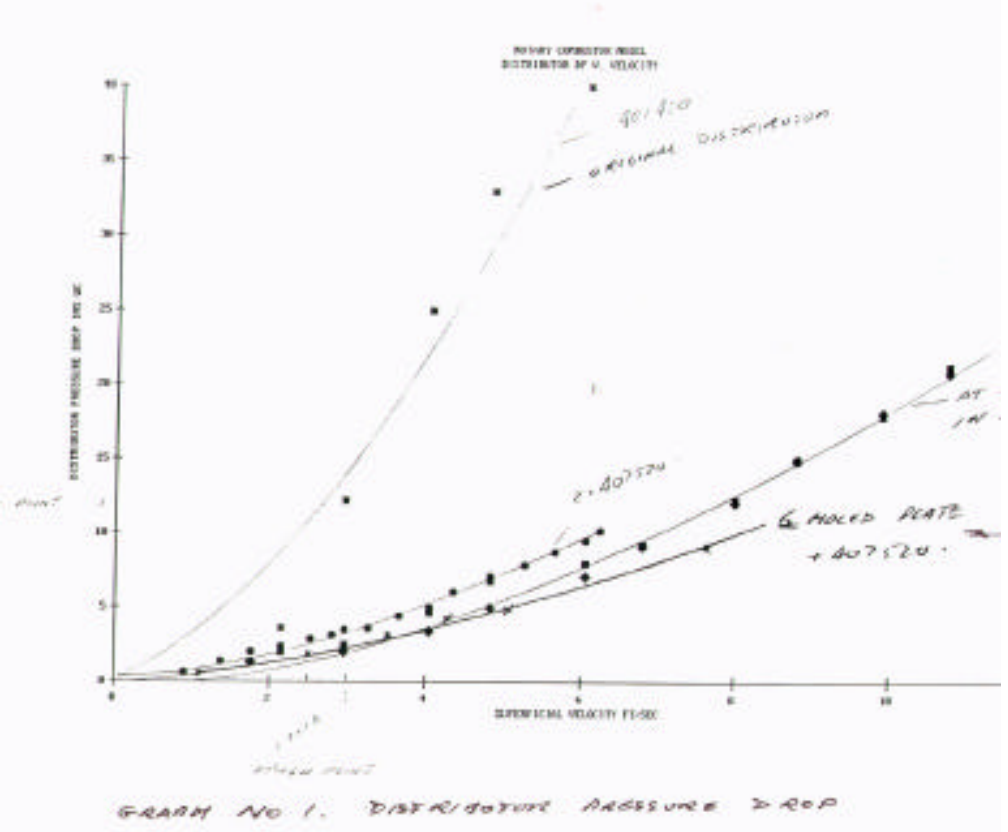
extent of mixing by observing and photographing redistribution of the dark-color sand from the bottom of the bed into the light-color sand surface layer.

The total pressure drop against bed velocity at $10 \mathrm{G}$ rotational speed was measured first. The bed showed the classic "fluidizing hump" at about 1.5 $\mathrm{ft} / \mathrm{sec}$, which is the theoretical fluidizing velocity for this sand. Above that velocity, little increase in $\mathrm{dP}$ was observed, proving that the bed was fluidized. Photographs were taken over the entire operating

range in two series of tests.

There was evidence of poor radial distribution in the first set of photos, so a more exhaustive second set of high-speed photos was taken. The second set of pictures showed good bottomto-top mixing at the interface between the layers, but displayed poor overall radial distribution in the bed (see Photograph No. 2 below). 


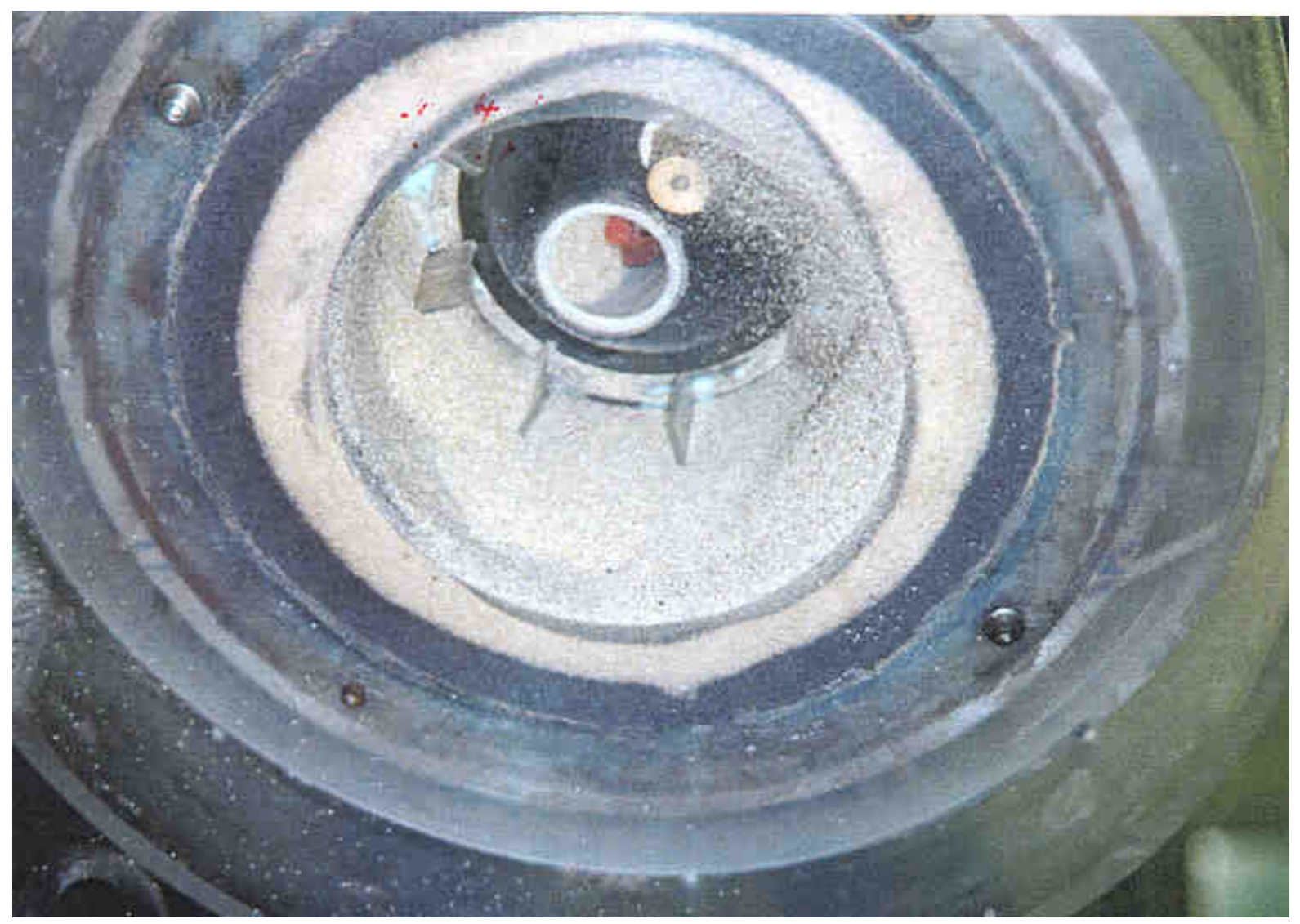

\section{Photograph No. 2 - Detail of flow test using two colors of sand and distribution fins.}

Consequently, a second composite distributor plate was manufactured with reduced (3.3\%) free area, fitted to the one-third-scale cold flow model, and both pressure drop verses velocity and radial distribution tests were completed. This configuration exhibited a higher $\mathrm{dP}$ at the design point $(2.7 \mathrm{ft} / \mathrm{s})$, but it was lower than anticipated (less than double). An improved radial distribution in the bed (the test objective) was observed, which was the objective of the distributor plate modification.

\subsubsection{Radial Fin Optimization}

During the new composite distributor tests, a brief test was performed using radial fins attached to the back plate and a baffle plate that dipped into the bed. With this configuration, the bed material was carried out at an unacceptably low velocity, i.e., $4 \mathrm{ft} / \mathrm{s}$. Consequently, the baffle plate fins were machined to prevent them from dipping into the bed. They are only required to distribute the incoming fuel material. With this arrangement a much more acceptable distribution was achieved (see Photograph No. 3 below). 


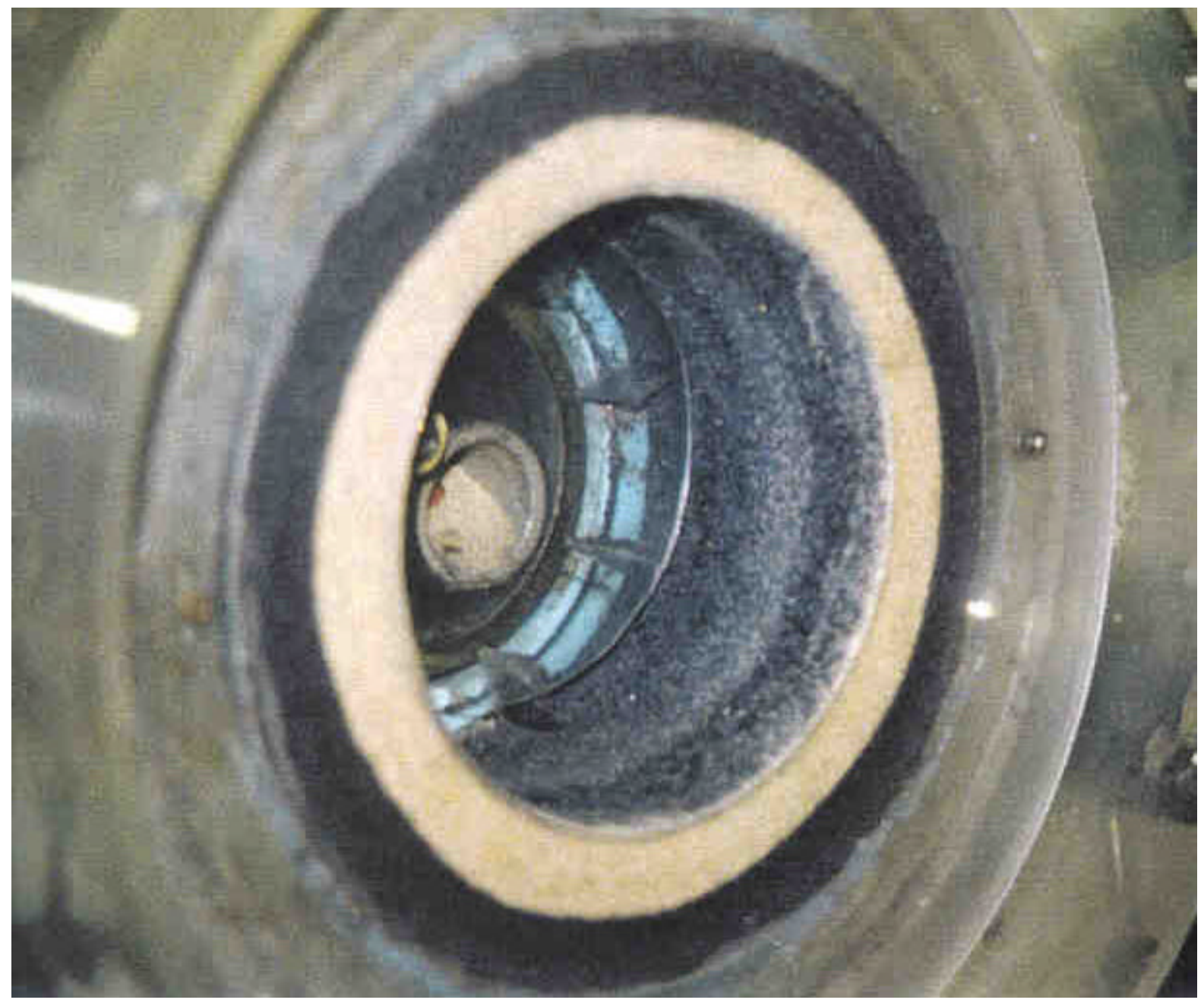

Photograph No. 3 - Flow test on model demonstrating good distribution. 
The radial fins also were remachined so that the fins did not enter into the fluid bed surface, and the new design was re-tested. The fins conveyed considerable radial acceleration to the incoming fuel particles (using sand in the test), but did not cause uneven bed surface distribution or cause unacceptable bed carryover as observed previously. These tests were considered preliminary and were repeated with more measurements in order to finally establish the fin and distributor configuration.

New material was obtained and a new fin configuration machined, assembled and positioned in the model where the fins are some 1/4" above the inner circumferential fluid bed surface. This configuration was tested up to a superficial velocity of nearly $3 \mathrm{ft} / \mathrm{sec}$ with a bed pressure drop of 8" WC. Photographic evidence of the results was obtained. This arrangement is an improvement compared to the longer vanes, since there is less interference with the bed surface. However, some depression of the bed still occurs towards the rear of the Rotary Combustor drum. The short fin arrangement was ultimately adopted and engineered for application in the prototype Rotary Combustor as shown on Drawing No. DOE3-1004/R0 attached in Appendix B. This fin arrangement is displayed in Photograph No. 4 below.

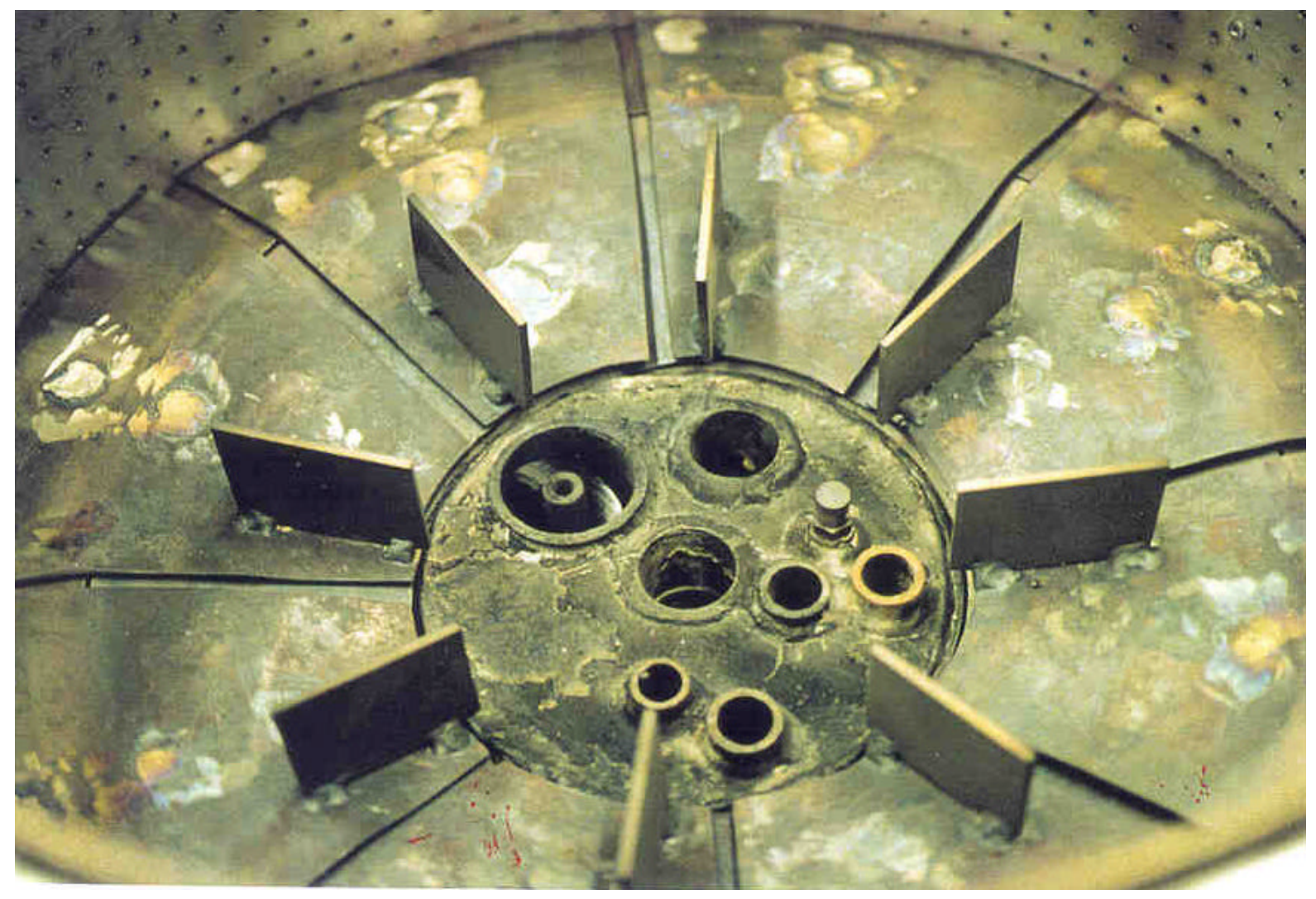

Photograph No. 4 - Distribution fins outside of coal conveying screw. 


\subsubsection{Other Modifications}

Apart from the distributor and radial fin design improvements described above, four other modifications were carried out to eliminate deficiencies in the original prototype:

- Brush seal replacement for the disc seal.

- New 3" long ash trough to connect the rotary drum to the $\mathrm{DeNO}_{\mathrm{x}}$ Firetube, including a new 3" ash outlet pipe and correspondingly larger slide gate valves.

- New pilot light position in the $\mathrm{DeNO}_{\mathrm{x}}$ Firetube.

- New weir design.

The brush seal replacement was implemented after comprehensive discussions with Pratt \& Whitney. Their recommendation was based on recent adoption of these seals for industrial gas turbines to replace the labyrinth seals used previously. The brush seal gave operational problems, which will be reviewed in the Operations discussion later in the report.

The extension of the ash trough and expansion of the outlet pipe and slide gate valve assembly, and repositioning of the pilot light were easily accomplished, and very effective in operation. The new weir design was actually carried out after the initial operating tests in response to the drum binding problem encountered at temperatures between $1600^{\circ} \mathrm{F}$ and $1700^{\circ} \mathrm{F}$. The objective is to better accommodate the expansion stresses at the higher temperatures. This modification also is discussed in the Summary of Operating Problems section later in the report. 


\subsection{Rotary Combustor Installation on CONSOL T-850P CNB Boiler}

The objective of this task is to assemble the various components of the modified Rotary Combustor installation and attach them to the CONSOL T-850P CNB boiler in South Park, Pennsylvania. It also is necessary to obtain a variance to the current permit to burn 60 tons of non-compliance coal in Allegheny County prior to starting the shakedown tests. This task comprises the preparation of various flow sheets and layout drawings, which include process instrumentation and control system, and safety system and interlock designs for the boiler, burner, coal feeder, limestone feeder and ash removal system.

This task was accomplished in its entirety. The Rotary Combustor was mounted on the T850P CNB boiler by installing a new burner register through the front steel pressure wall on the North end of the existing boiler. This required a separate engineering subcontract, which included boiler code pressure testing of the modified equipment. The proposed project plan was to replace the natural gas burner at the opposite end of the CNB boiler; however, CONSOL Engineering deemed it necessary to maintain the natural gas burner for firing during the winter months when the original schedule slipped due to contractual and installation delays. A new tertiary air register and refractory quarl also was fabricated and installed. In addition, steelwork was positioned on the front of the boiler to support the Rotary Combustor and provide for easy access during the testing phase.

The aggregate installation also included refurbishing the CNB boiler baghouse, connecting to the natural gas supply for heat-up of the rotary drum prior to introducing coal, installing two fans to supply primary and secondary/tertiary air and three control valves for individual control of each air supply line, and installing the Moore Products APACS cabinet and PC, together with the required control instrumentation as displayed on the primary P\&ID (piping and instrumentation drawing). Photographs of the Rotary Combustor installation and the Primary and Secondary Air Supply System alongside the CNB boiler are displayed on the next two pages in Photographs No. 5 and No. 6, respectively.

The CONSOL R\&D Safety Program includes a safety and design review of all pilot plant and field trial equipment assemblies prior to their operation. A formal R\&D Safety Checklist is required for the review. An Operating Manual also is prepared for Operator training. The Operating Manual contains sections on Emergency Procedures, Unit Description, Operator Responsibilities, Operating Procedures for Start-up, Normal Operation and Routine Shutdown, Operating Hazards, Procedures for Modification, and Waste Disposal Procedures. The R\&D Safety Checklist and Operating Manual for the Rotary Combustor Installation on the T-850P CNB Boiler is included in Appendix A. Items added to the installation as a consequence of the safety review included a shut-off valve at the Oxidizer exit, $\mathrm{CO}$ monitor in the CNB boiler work area, and a vent line from the rupture disc to exhaust the Rotary Combustor gases outside the Utility Building during an emergency over-pressure event. 


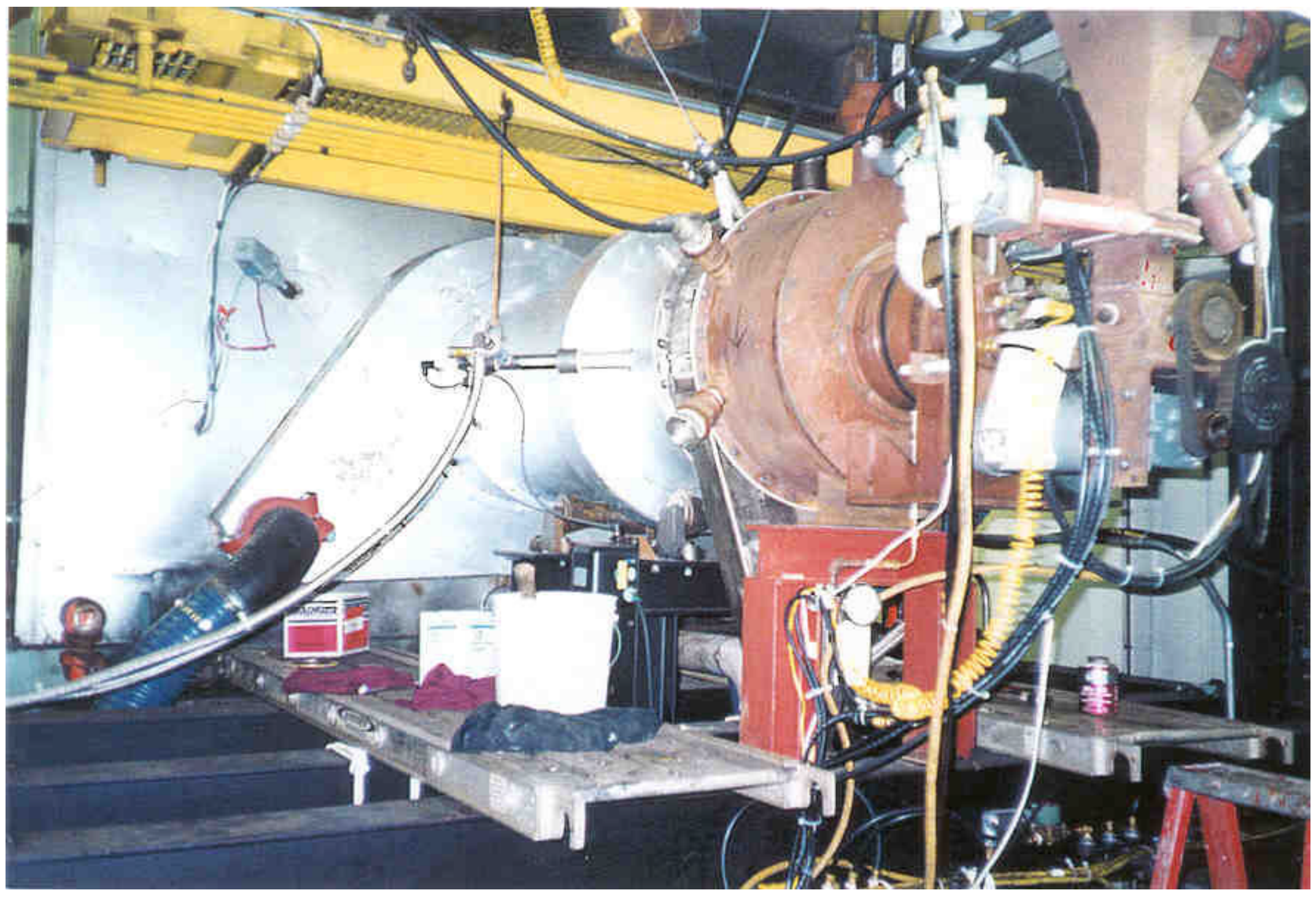

Photograph No. 5 - Rotary Combustor mounted on CNB T850-P boiler at the CONSOL Energy South Park site. 


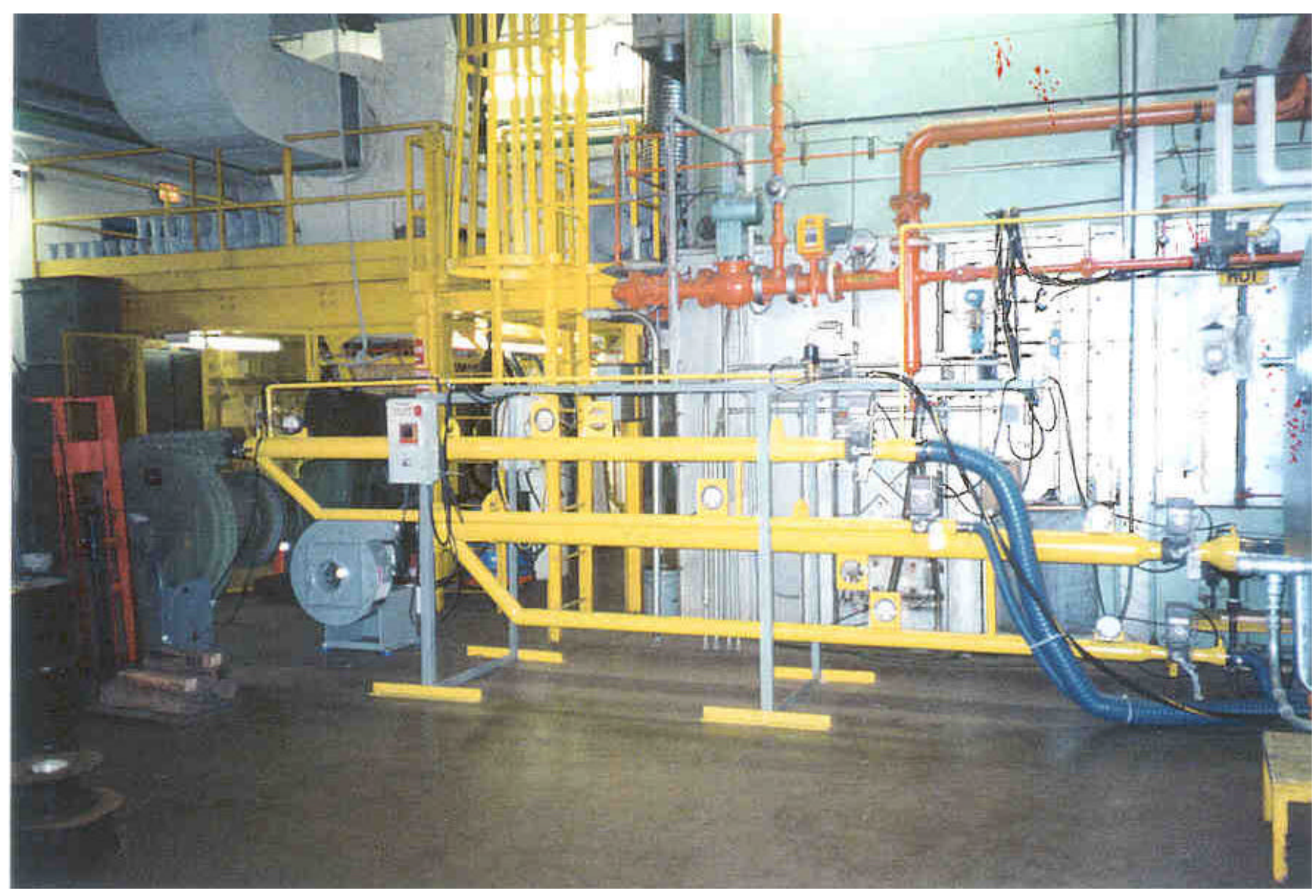

Photograph No. 6 - Primary and secondary air flow fans with control valves and flow measurement devices alongside the CNB boiler. 


\subsection{Rotary Combustor Test Program}

There are three key goals for this task: to verify the basic soundness and limitations of the equipment in shakedown tests, to establish efficiency and emissions control capacity by varying the process feeds parametrically, and to establish the viability of the design for an industrial-scale demonstration by an endurance test.

All three goals established for this task were not accomplished. Several equipment problems were encountered during start-up and shakedown tests. When combined with delays in the installation of the Rotary Combustor on the CNB boiler, these reduced the resources available for this phase of the project. The equipment problems were not completely resolved; they are described below in the Shakedown Test Results section of the report.

In initial operations tests, sustainable operation for greater than two hours was demonstrated burning a high-Btu solid fuel, metallurgical coke; however, no long-term endurance test was completed with coke or coal. The principle of temperature control by steam injection with the fluidizing air into the bed was demonstrated; however, steam flow control was not sufficiently fine to permit development of automatic feedback control. Very preliminary emissions data were obtained and are reported here.

This task included the test schedule and objectives outlined in the table below. Five different test campaigns were completed between September 1999 and June 2000. Three Shakedown tests were conducted in September 1999, October 1999 and January 2000. The tests characterized the performance of the new distributor plate and brush seal, and revealed several problems that were not completely resolved. Two Operations tests were conducted to demonstrate continuous operation for more than two hours and gather emissions data, the first in April 2000, and the second in June 2000. The Shakedown and Operations test results are discussed separately in the appropriately titled sections of the report below.

Table No. 3: Rotary Combustor Test Schedule and Objectives

\begin{tabular}{|c|c|c|c|}
\hline Test & Dates & Objective & Fuel \\
\hline Shakedown & $\begin{array}{l}\text { September } 1999 \\
\text { Sept. } 14 \\
\text { Sept. } 29 \\
\text { October } 1999 \\
\text { Oct. } 18 \\
\text { Oct. } 19 \\
\text { Oct. } 20 \\
\text { January } 2000 \\
\text { Jan. } \\
\end{array}$ & $\begin{array}{l}\text { Pressure drop tests } \\
\text { Pressure drop tests } \\
\text { Pressure drop tests } \\
\text { Pressure drop tests } \\
\text { Pressure drop tests } \\
\text { Test plated land ring }\end{array}$ & $\begin{array}{l}\text { Natural gas } \\
\text { Natural gas } \\
\text { Natural gas } \\
\text { Natural gas } \\
\text { Natural gas } \\
\text { Natural gas }\end{array}$ \\
\hline Operations & $\begin{array}{l}\text { April } 2000 \\
\text { Apr. } 5 \\
\text { Apr. } 6 \\
\\
\text { June } 2000 \\
\text { June } 5 \\
\text { June } 7 \\
\text { June } 8 \\
\end{array}$ & $\begin{array}{l}\text { Test brush seal lubicant } \\
\text { Test steam injection \& } \\
\text { measure emissions } \\
\text { Operations test } \\
\text { Measure emissions } \\
\text { Measure emissions }\end{array}$ & $\begin{array}{l}\text { Coke } \\
\text { Coke } \\
\text { None } \\
\text { Coke } \\
\text { Coke } \\
\end{array}$ \\
\hline
\end{tabular}




\subsubsection{Shakedown Test Results}

Three Shakedown test campaigns were conducted beginning in September 1999, and continuing in October 1999 and January 2000. In each case, one-week tests were planned, but problems with loss in pressure drop through the rotating drum (between the combustion air plenum and the fluid-bed) and binding of the rotating drum caused the tests to be terminated prematurely. A summary of the operations and problems is given in the discussion below.

Shakedown tests were initiated in September 1999. The first step was to complete pressure drop tests to calibrate the new distributor plate and brush seal combination in the Rotary Combustor. The first such test was completed on September 14, 1999. The new pilot light also was commissioned during this test. Some adjustments were necessary to maintain a stable flame on the surface of the bed that is detected by the flame scanner. The flame scanner was repositioned in the side view port. The water spray system was added to maintain the fluid-bed temperature below the specified limit, $1800^{\circ} \mathrm{F}$.

Two trial runs of the Rotary Combustor were completed burning natural gas with a hot sand bed on September 14 and September 29. A reduction in pressure drop across the distributor was experienced, and the rotating drum tended to bind at temperatures between $1,600^{\circ} \mathrm{F}$ and $1,700^{\circ} \mathrm{F}$.

At the end of these two tests, the rotary drum was disassembled to inspect the brush seal. The brush seal mounted in the Rotary Combustor stator is pictured in Photograph No. 7 below. The brush itself appeared to be in fine condition, but there was evidence of wear on the rotor, as displayed in Photograph No. 8 at the top of the next page. The wear amounted to roughly 0.003 ".

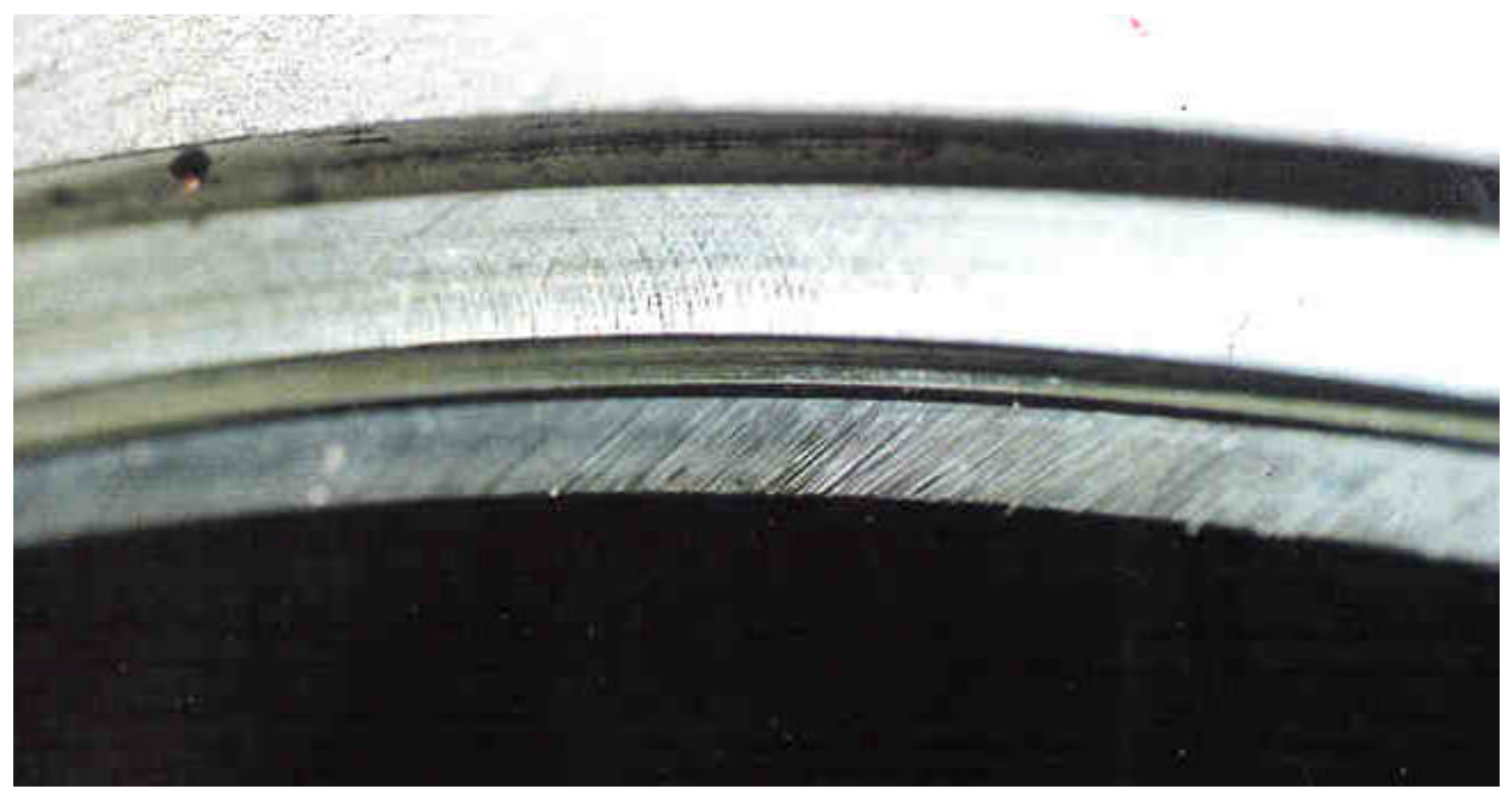

Photograph No. 7 - Pratt \& Whitney brush seal mounted in stator. 


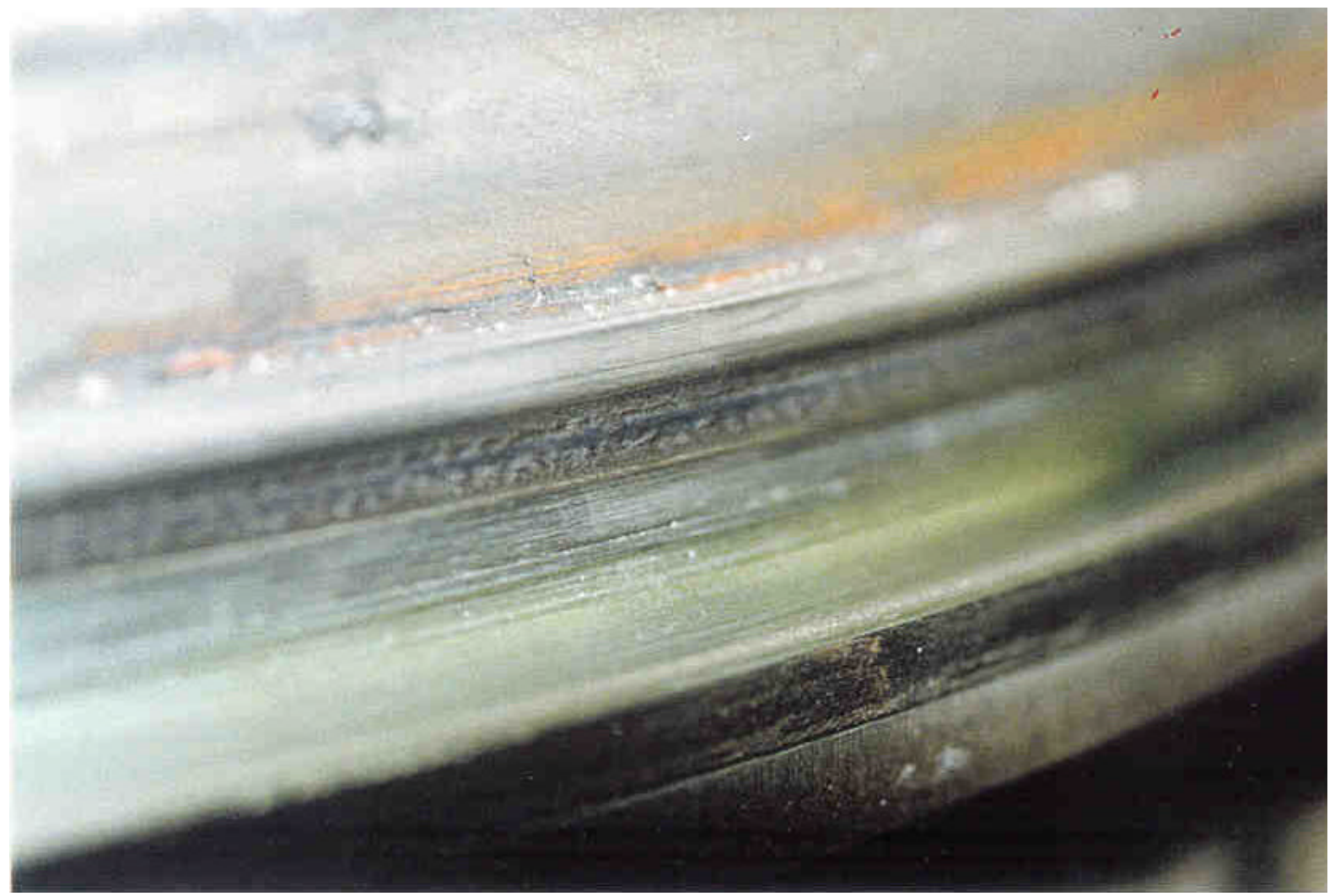

Photograph No. 8 - Galling of rotor by brush seal.

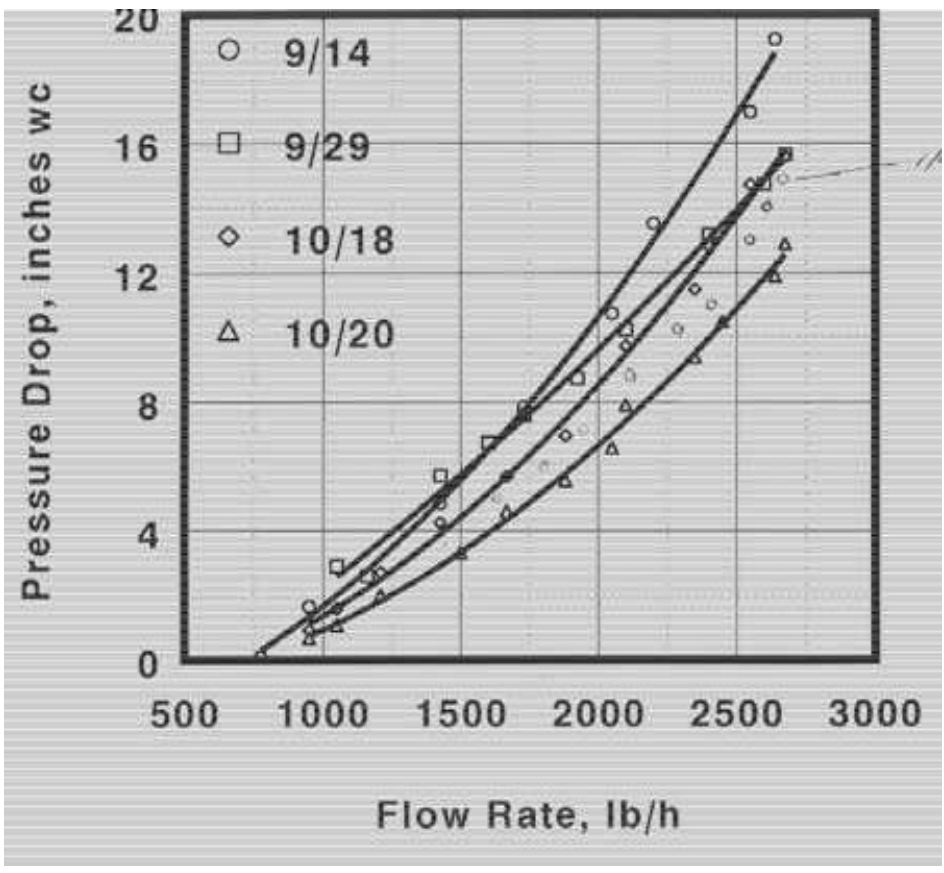

Pressure Drop graph No: 2
Discussions were conducted with Pratt \& Whitney, manufacturer of the brush seal, regarding the observed wear. Pratt \& Whitney indicated that the described wear was normal, and should not effect the performance of the seal. Careful inspection of the area immediately adjacent to the seal revealed a gap between the distributor plate and cage. This gap was sealed with high-temperature silicon to prevent air escaping between the components. The unit was reassembled and further tests conducted.

A second series of tests were conducted between October 18 and

October 20. The pressure drop through the distributor for the October 18 tests was the same as that observed for the 
September 29 runs. These results suggest that the brush seal performance was unchanged from the previous tests, and no improvement was gained by applying the silicon sealant to the gap between the distributor plate and cage.

More serious was the severe binding of the drum after running at operating temperature while firing the fluid bed with gas. This occurred a number of times over the three days of testing. At the end of this test period, the distributor pressure drop was re-tested, and showed further deterioration by $23 \%$, as displayed on Graph No. 2. The Rotary Combustor was once again dismantled to investigate the cause for the binding.

Further discussion with Pratt \& Whitney revealed that incompatible materials were selected for the brush bristles and the rotor from a hardness point-of-view. The brush bristles were fabricated from cobalt, with a Vickers hardness of about 500, while the rotor was constructed from 304 stainless steel, with a hardness of 130. This caused serious galling of the softer 304 material, resulting in leakage through the seal and the observed loss in pressure drop through the rotary drum. Pratt \& Whitney suggested metal spraying the rotor with chrome carbide to both restore the rotor dimensions and provide a much harder and more compatible surface for the existing brush bristles. Consequently, the existing rotor was metal sprayed to Pratt \& Whitney specifications.

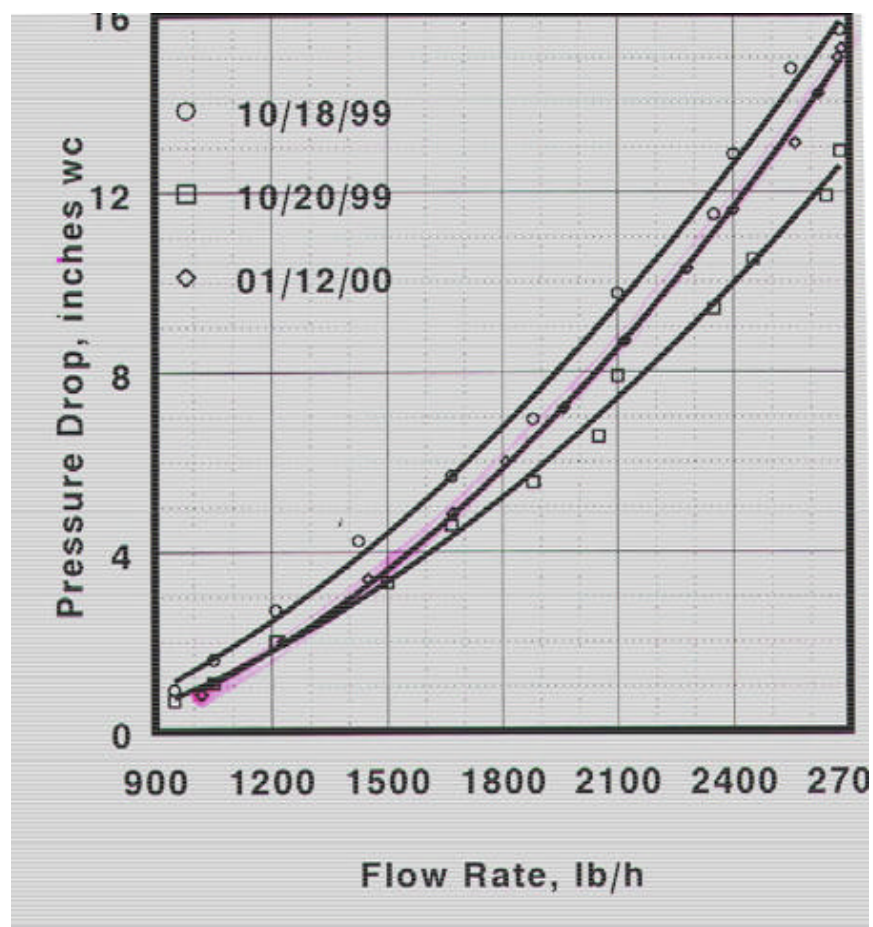

Pressure Drop Graph No: 3

Further examination of the rotary drum parts indicated that the expanding weir edge interfered with the stationary ring supporting the insulation, and also caused the drum to stop rotating at temperatures between $1,600^{\circ} \mathrm{F}$ and $1,700^{\circ} \mathrm{F}$. As the weir expanded more than anticipated, a new design with greater clearances was manufactured and fitted (see Drawing No. DOE31002/R1 attached in Appendix B).

After reassembly, the Rotary Combustor was ready for testing in January 2000. Cold test pressure drop results shown in Graph No. 3 indicate that the pressure drop across the distributor had been restored to near early-October figures. During hot tests, the rotating drum continued to give binding problems. It was speculated that the probable cause was the new interference fit of the metal-sprayed rotor and the brush seal. To overcome this, the $2 \mathrm{hp}$ drive motor was replaced with a $3 \mathrm{hp}$ drive motor. In continued tests, frozen coal in the feed screw on the coal hopper outside the building caused the conveyor motor to burn out, and ensuing delays. 


\subsubsection{Operations Test Results}

Two one-week Operations Test campaigns were conducted, one in April 2000, and the final campaign in June 2000. At this time the project funds were expended. These tests were conducted to demonstrate continuous operation for more than two hours on a high-Btu solid fuel (metallurgical coke), to investigate fluid-bed temperature control issues, and to gather preliminary emissions data. The results are summarized in the discussion below.

Operations tests were initiated in April 2000. The high-temperature performance of the Rotary Combustor was maintained by spraying silicon and molybdenum lubricants onto the brush seal before operating at temperature. A successful burn on coke was achieved during the week.

Sustainable operation burning metallurgical coke was achieved on April 5, 2000, and the unit was run in the gasifier mode for about 1.5 hours. Coke was selected as the initial solid test fuel for two reasons: coke contains virtually no volatile matter, and thus gives lower heat release in the drum, and coke displays a lower tendency to clinker in the fluid bed, a problem that precluded long term tests in the original series of tests. It was still difficult to fully dampen temperature oscillations in the drum, but reasonable control was achieved by constant manual operation. 
Flue gas emission levels were measured in the flue gas from the boiler, but a high ingress of air through the stoker doors in the bottom of the CNB boiler diluted $\mathrm{NO}_{\mathrm{x}}$ and $\mathrm{SO}_{2}$ readings, which consequently approached zero. The highest $\mathrm{CO}$ figure was about 73 ppmv, lower than expected in gasifier mode with no tertiary air. The bottom doors at the front of the old stoker were sealed before tests the next day.

A second run on April 6, 2000 was conducted burning coal for over two hours, with roughly 1.5 hours in gasifier mode. The Graphs No. 4 and No. 5 display air and gas flows on the former, and fluid-bed and $\mathrm{DeNO}_{\mathrm{x}}$ Firetube temperatures on the latter. Although the rotating fluid-bed temperature oscillated, it was mostly between $1,500^{\circ} \mathrm{F}$ and $1,600^{\circ} \mathrm{F}$ over the period that the unit was operated in the gasifier mode. Steam flow was between 10 and $29 \%$ of full range flow, which was 10 to $268 \mathrm{pph}$ of steam. As the coke rate was between 100 and 175 pph, the latter steam rate was actually too high, as ideally the ratio should be nearly $1: 1$. The 2" valve was actually too large for the application, and larger than specified in the valve installation request.

The $\mathrm{DeNO}_{\mathrm{x}}$ Firetube temperature exceeded $2000^{\circ} \mathrm{F}$, and readings as high as $2,176^{\circ} \mathrm{F}$ were obtained from the separate digital indicator. This appeared to produce some dissociation of the $\mathrm{NO}_{\mathrm{x}}$, because the highest level recorded for this test is $404 \mathrm{ppmv}$ (corrected to $4 \%$ excess oxygen). For most of the test duration the corrected $\mathrm{NO}_{\mathrm{x}}$ level is roughly $200 \mathrm{ppmv}$. This value is more than twice the target value of less than $100 \mathrm{ppmv}$.

The $\mathrm{CO}$ measured in the flue gas varies between 435 and 5,038 ppmv (corrected to 4\% excess oxygen). With no tertiary air, this value is the correct order. Theoretical estimates produce approximately $17 \% \mathrm{CO}$ in the $\mathrm{DeNO}_{\mathrm{x}}$ Firetube. As some burning is observed in the boiler enclosure (see Photograph No. 9 at the top of the next page), 5\% CO at the boiler exit is consistent with the approximate analysis of the syngas from theoretical considerations (see SBIR-I report on Rotary Combustor dated May 10, 1994). The measured $\mathrm{SO}_{2}$ levels ranged from 250 to 342 ppmv (corrected to $4 \%$ excess oxygen), but as limestone was not being injected with the coke, this was not significant.

Further tests were curtailed until the next day when the conveyor motor burned out. This appeared to be caused by a defect in the upper level sensor of the buffer hopper, allowing the hopper to flood with coal, consequently jamming the screw. The Rotary Combustor was shut down on April 7 until the conveyor motor was repaired. The level probe also was rewired to prevent reoccurrence of the event. Further tests were subsequently delayed until June 2000 because the variable speed drive used for the rotary drum was temporarily moved to another project. 


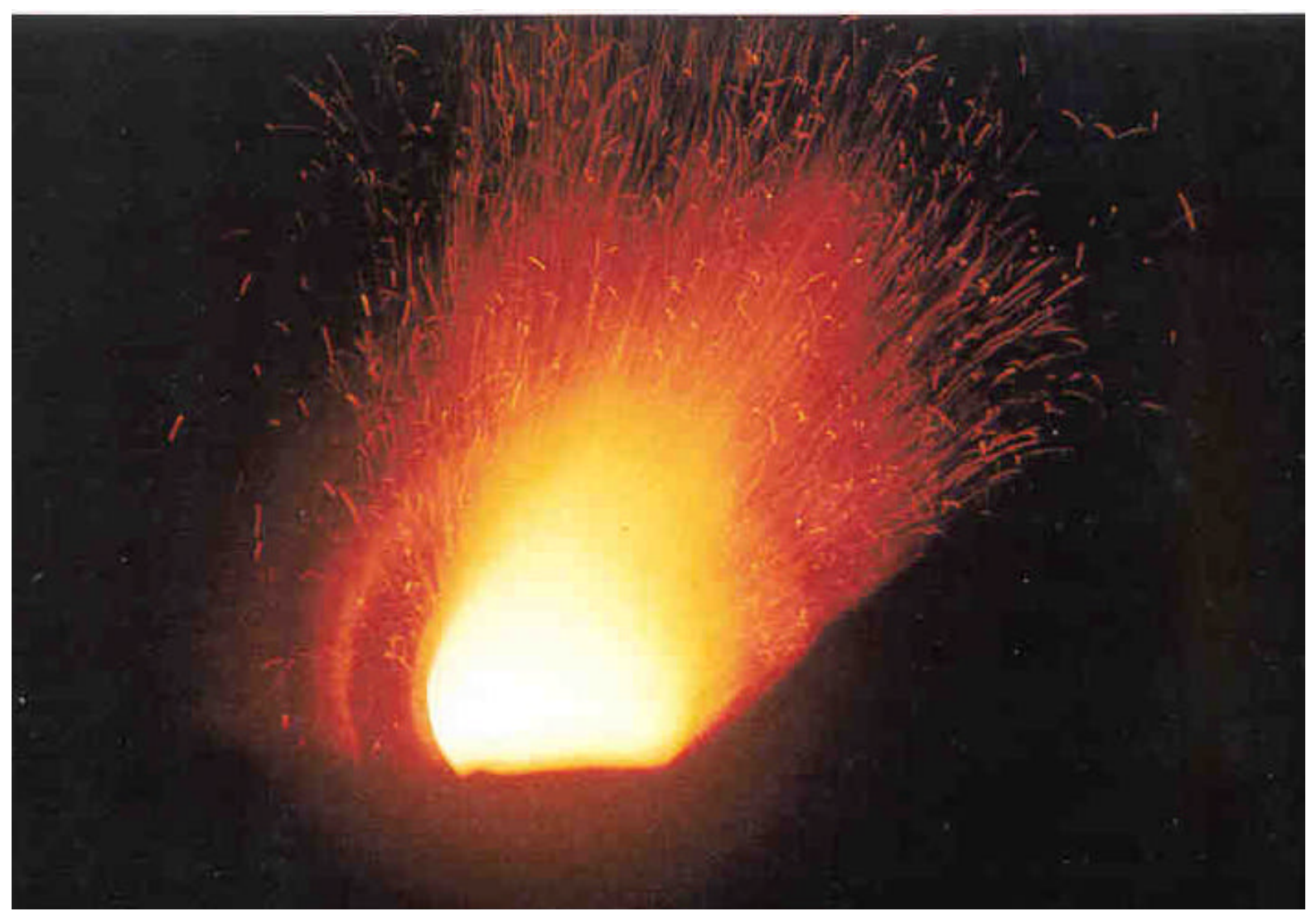

\section{Photograph No.9 - Rotary Combustor flame with no tertiary air.}

The final campaign was initiated on June 5. The Rotary Combustor was fired again with coke on June 7, but it was hampered by coal sticking in the chute. A pneumatic vibration device was added to the buffer hopper slope.

Three runs were completed on June 8, but only the third was over two hours duration. Again the temperature of the bed is observed to oscillate significantly. Graph No. 3 shows temperature results for all three operating periods. After some practice, some semblance of control was achieved during the second hour of the third run. Photograph No. 10 at the top of the next page.

During this period, the coke firing rate was about $150 \mathrm{pph}$, or 2.1 million Btu/hr. The temperature in the $\mathrm{DeNO}_{\mathrm{x}}$ Firetube was 2,250 to $2,350^{\circ} \mathrm{F}$. To achieve these conditions, the secondary air was set at $60 \%$ of the full range value, or 1,600 pph. The measured $\mathrm{NO}_{\mathrm{x}}$ during this run varies between 90 and $271 \mathrm{ppmv}$ (corrected to $4 \%$ excess oxygen). The corrected $\mathrm{SO}_{2}$ level ranges between 67 and 270 ppmv. Again, no limestone was injected. 


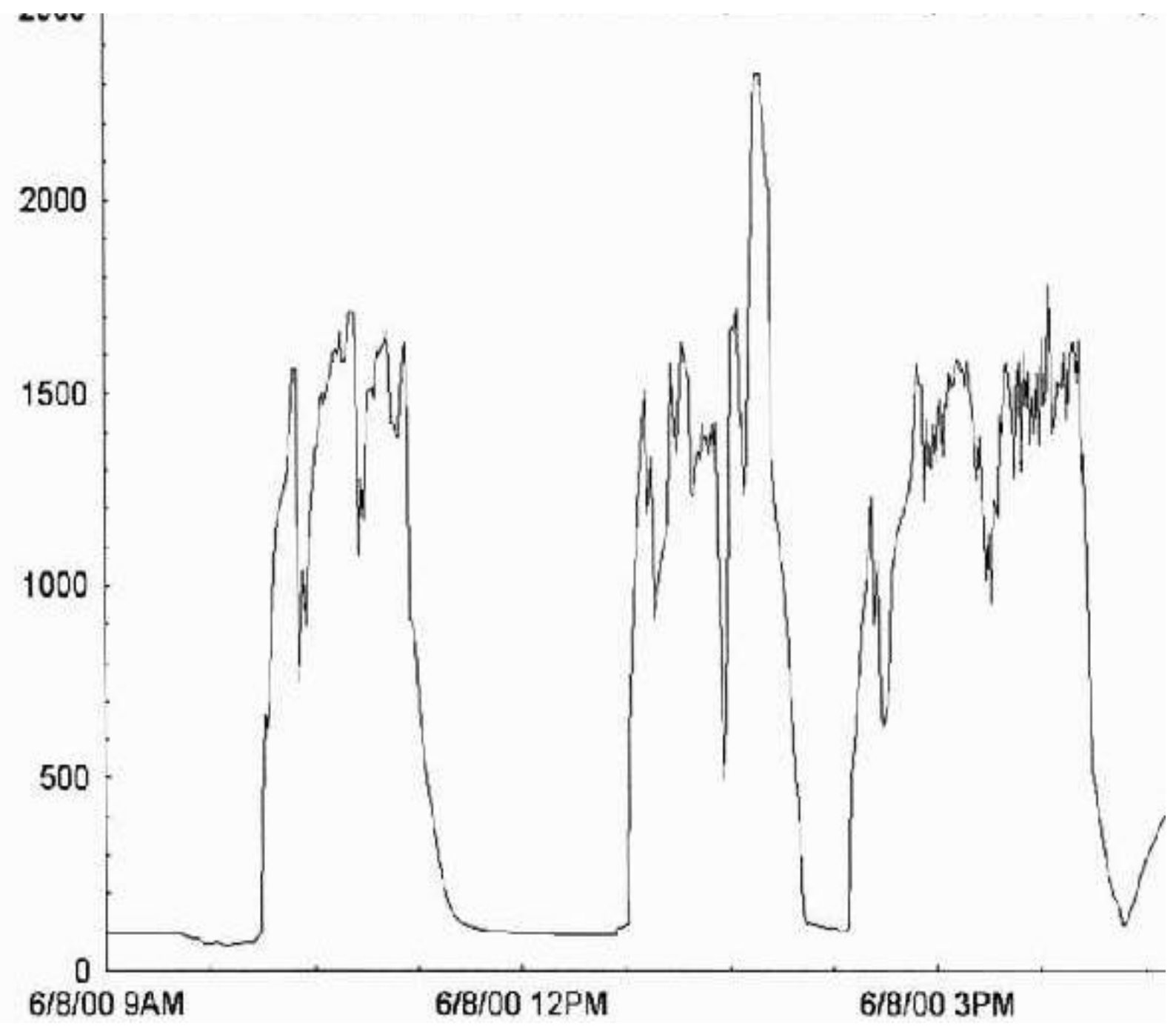

Graph No: 3 Temperature - Time Graph for Final Tests 


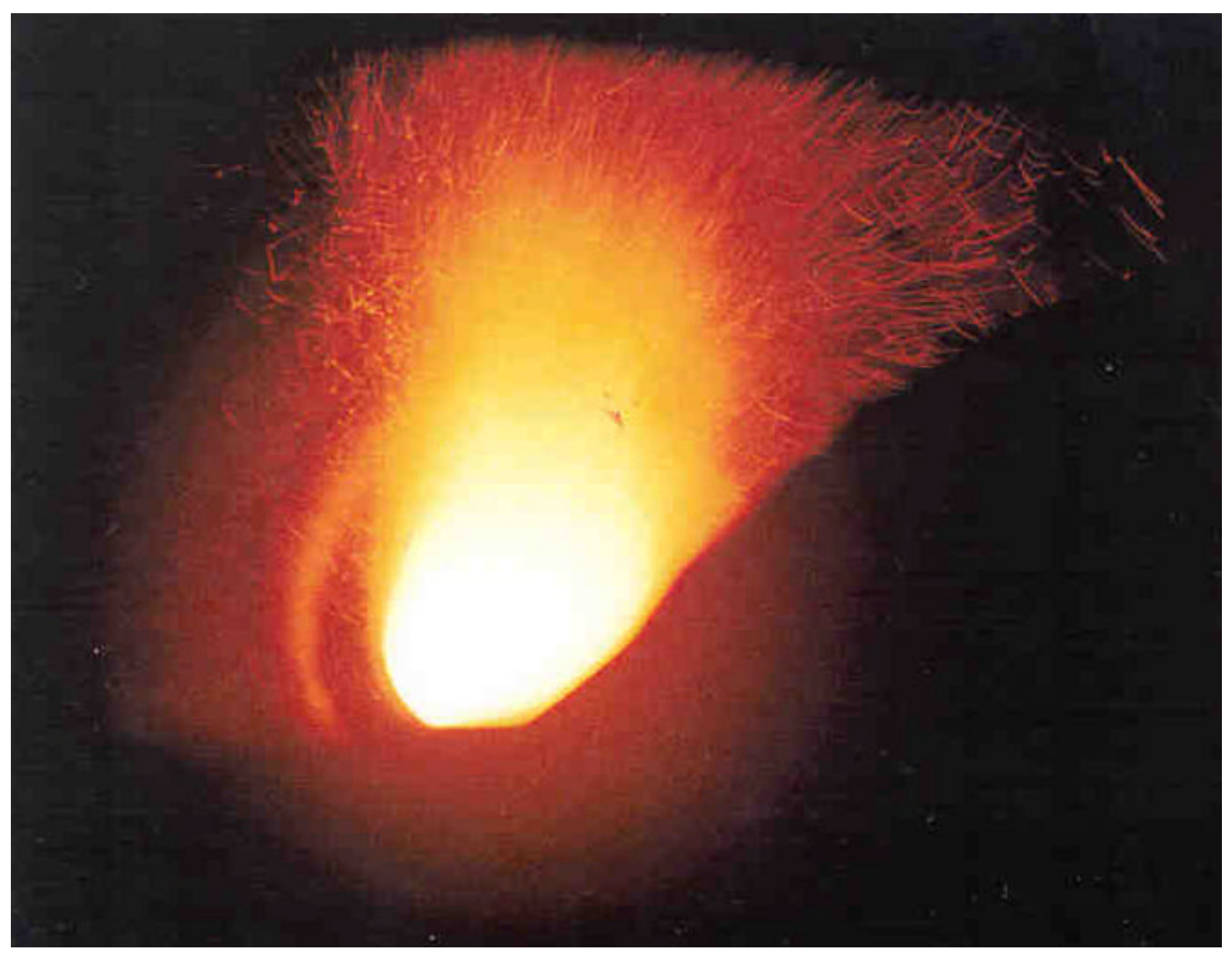

Photograph No. 10 - Rotary Combustor flame with tertiary air on.

The emission results recorded above are impacted by the temperature oscillations in the fluid-bed, as much as $\pm 200^{\circ} \mathrm{F}$, as displayed in Graph No. 9. Reasonable control of the bed temperature while burning coke was best achieved by using a small amount of natural gas as a make-up fuel, as the response of the solid fuel feed was too slow to be effective.

One initial objective was to demonstrate the use of steam for temperature control, but the large gate valve did not give sufficiently fine control of steam flow. The temperature oscillation exhibits a negative impact on the steadiness of combustion and subsequent emissions from the Rotary Combustor burner. Attempts to operate at steady temperatures in the fluid-bed were conducted on June 9, but no improvement was evident. The idea of running continually over night on manual control was abandoned due to constraints in both skilled manpower and the project budget. 


\subsubsection{Summary of Operating Problems}

The table below identifies the mechanical problems observed during the shakedown testing, by component. It also gives probable causes and recommended remedial actions at the time the problems were encountered. Several of these problems were addressed during the shakedown tests and at least temporarily resolved.

Table No. 4: Rotary Combustor Mechanical Problems

\begin{tabular}{|c|c|c|c|}
\hline Component & Problem & Probable Causes & Remedial Action \\
\hline 1. Rotating drum & Binding & $\begin{array}{l}\text { Overheated bearing } \\
\text { Choice of seal }\end{array}$ & $\begin{array}{l}\text { Cool bearing housing } \\
\text { Alternative design }\end{array}$ \\
\hline $\begin{array}{l}\text { 2. Brush seal \& } \\
\text { Rotor land ring } \\
\end{array}$ & Wear & Choice of materials & $\begin{array}{l}\text { Plate land ring (harden) } \\
\text { Lubricate brush seal }\end{array}$ \\
\hline 3. Distributor plate & Non-uniform flow & $\begin{array}{l}\text { Air quality } \\
\text { Sand leakage }\end{array}$ & $\begin{array}{l}\text { Filter air } \\
\text { Clean Dynapore }{ }^{\mathrm{TM}} \text { membrane }\end{array}$ \\
\hline 4. Weir & Sand leakage & $\begin{array}{l}\text { Erosion of insulation } \\
\text { Warping of ring }\end{array}$ & Alternative design \\
\hline 5. Thermocouple & Interference with bed & Positioning & Alternative design \\
\hline
\end{tabular}

An overheated bearing assembly does not now appear to be the cause of the rotating drum binding problem. The drum binding and seal wear problems appear to have the same cause. The binding likely occurred between the brushes and rotor land ring in the seal when the seal heated up. The wear occurred just prior to binding because the rotor land ring was constructed from a softer metal than the brushes. The brushes are hard cobalt bristles and the rotor land ring is a significantly softer 304 stainless steel. The drum binding and rotor land ring wear problems were resolved simultaneously by plating the 304 stainless steel rotor land ring with a chrome carbide plasma spray, and lubricating the seal with silicon and molybdenum lubricants immediately prior to operating the Rotary Combustor.

After the Dynapore membrane was cleaned, the fluid-bed air distribution problems did not reoccur. The weir was redesigned and a new weir fabricated and installed prior to the final two test campaigns. This design is displayed in Drawing No. DOE-1002/R0 in Appendix B. The problem of fluid-bed surface interference by the bed thermocouple was reduced by using a smaller thermocouple with a stainless steel brace.

\subsection{4 $\underline{\text { Summary of Accomplishments }}$}

Unlike previous tests at Detroit Stoker, sustained operation of the prototype Rotary Combustor was accomplished burning a high-Btu fuel, metallurgical coke. The prototype Rotary Combustor was operated with coke in gasifier mode on two occasions. Fluid-bed temperature spiking was minimized with manual control of the feeds (coke, air and steam), and no clinker formation problems were encountered in either test. All previous prototype Rotary Combustor coal burning tests at Detroit Stoker were conducted with air only, and were terminated due to uncontrolled temperature spikes and clinker formation in the bed. The ash clinkers caused fluid-bed distribution problems and plugged the bottom ash outlet. 
A summary of emissions levels for the final tests in April and June is given in Table No. 5 below. All reported emissions levels are corrected to $4 \%$ excess oxygen. The $\mathrm{SO}_{2}$ emissions objective is not demonstrated because limestone was not added to the bed for the short duration tests. The $\mathrm{NO}_{\mathrm{x}}$ emissions objective is not demonstrated for a sustained test, although the low end of the results reported for the June 8 test is slightly below $100 \mathrm{ppm}$.

\section{Table No. 5: Emissions Summary}

\begin{tabular}{||l|l|r|r|r|r||}
\hline \hline Test Date & Operating Condition & $\begin{array}{c}\text { CO, } \\
\text { ppmv }\end{array}$ & $\begin{array}{c}\mathbf{N O}_{\mathbf{x}}, \\
\mathbf{p p m v}\end{array}$ & $\begin{array}{c}\mathbf{N O}_{\mathbf{x}}, \\
\mathrm{lb} / \mathbf{M M} \text { Btu }\end{array}$ & $\begin{array}{c}\mathbf{S O}_{2}, \\
\text { ppmv }\end{array}$ \\
\hline April 6 & Gasifier - w/o tertiary air & $435-5,038$ & $\sim 200$ & $\sim 0.28$ & $250-342$ \\
\hline June 8 & Gasifier - with tertiary air & na & $90-271$ & $0.13-0.38$ & $67-270$ \\
\hline
\end{tabular}

Finally, Table No. 6 below summarizes the accomplishments of the Rotary Combustor testing on the CONSOL Energy T-850P CNB boiler. The two principal accomplishments are sustained operation burning a high-Btu fuel, and operation in the gasifier mode. The concept of using steam injection with the plenum air for temperature control in the fluid bed is demonstrated. The out-of-control temperature spikes were eliminated. The prototype Rotary Combustor was operated with coke in gasifier mode on two occasions. Fluid-bed temperature spiking was minimized with manual control of the feeds (coke, air and steam), and no clinker formation problems were encountered in either test.

Table No. 6: Summary of Accomplishments

\begin{tabular}{||l|l||}
\hline \multicolumn{1}{||c|}{ Demonstrated } & \multicolumn{1}{c|}{ Not Demonstrated } \\
\hline Sustained operation burning a high-Btu solid fuel (coke) & Fine/automatic temperature control \\
\hline Steam injection/gasifier mode & Very low $\mathrm{NO}_{x}$ emissions \\
\hline \hline
\end{tabular}

The carbon-steam reaction is actually endothermic, and requires heat from the carbon-air reaction to satisfy the energy requirements for reaction. The water-gas shift reaction (COsteam reaction) is only slightly exothermic, and occurs at much slower rates than the CO-air reaction.

\section{Carbon-oxygen reactions}

$$
\begin{array}{lll}
\mathrm{C}_{(\mathrm{s})}+1 / 2 \mathrm{O}_{2} & \mathrm{CO} & \Delta \mathrm{H}_{\mathrm{R}}{ }^{0}=-110.5 \mathrm{~mJ} / \mathrm{kmol} \\
\mathrm{CO}+1 / 2 \mathrm{O}_{2} & \mathrm{CO}_{2} & \Delta \mathrm{H}_{\mathrm{R}}{ }^{0}=-283.1 \mathrm{~mJ} / \mathrm{kmol}
\end{array}
$$

\section{Carbon-steam reactions}

$$
\begin{array}{lll}
\mathrm{C}_{(\mathrm{s})}+\mathrm{H}_{2} \mathrm{O} & \mathrm{CO}+\mathrm{H}_{2} & \Delta \mathrm{H}_{\mathrm{R}}{ }^{0}=+131.4 \mathrm{~mJ} / \mathrm{kmol} \\
\mathrm{CO}+\mathrm{H}_{2} \mathrm{O} & \mathrm{CO}_{2}+\mathrm{H}_{2} & \Delta \mathrm{H}_{\mathrm{R}}{ }^{0}=-41.0 \mathrm{~mJ} / \mathrm{kmol}
\end{array}
$$


Thus, the temperature of the fluid-bed may be controlled by controlling the ratio of steam to air in the fluidizing media. The fluid-bed temperature increases with increasing oxygen content in the inlet stream and decreases with increasing steam content in the inlet stream.

The primary Rotary Combustor operating problem remains control of the fluid-bed temperature. Although improvements in operations were made, steam flow control was manual, and very coarse. To accomplish stable Rotary Combustor operation will require finer control of the steam flow to the rotary drum air plenum, and development of an algorithm for automatic control using the Moore APACS ${ }^{\mathrm{TM}}$. This is the recommended succeeding step in the development of the Rotary Combustor for industrial use. At that time, the emissions objectives can be tested. 


\subsection{Marketing/Commercialization Discussion}

The Rotary Combustor is the only technology that offers the potential for simultaneous control of $\mathrm{NO}_{\mathrm{x}}$ and $\mathrm{SO}_{2}$ emissions using a single device for burning coal. It is a direct replacement for pulverized coal burners in industrial steam generators. The Rotary Combustor technology for use burning coal in steam generators competes with three other technologies for controlling $\mathrm{NO}_{\mathrm{x}}$ and $\mathrm{SO}_{2}$ emissions: 1. low- $\mathrm{NO}_{\mathrm{x}}$ burners, SNCR and SCR, 2. flue gas scrubbers, and 3. emission credits.

When this project was proposed in 1996, it was anticipated that the Rotary Combustor would share in the revenue from each of these markets. The burner market in 1994 was less than $\$ 100$ million. However, in 1995, the burner market expanded by 37\%, from 611 units to 840 units according to the American Boiler Manufacturers Association. A 1994 survey by the Energy Information Association indicated that $\$ 1.3$ billion was planned for installing scrubbers on 15 units in 1995 for Phase 1 compliance with the 1990 Clean Air Act Amendments. In 1995, the emission credits market was $\$ 106$ million. It the Rotary Combustor is demonstrated, it is a very attractive, low-cost option to either scrubbers, or the combination of low- $\mathrm{NO}_{\mathrm{x}}$ burners and emission credits.

Of the more than $265 \mathrm{GW}$ of coal-fired capacity in the United States, $89 \mathrm{GW}$ will require steps beyond fuel switching to comply with the 1990 Clean Air Act Amendments in the year 2000. As of 1996, only $21.3 \mathrm{GW}$ had installed scrubbers, repowered or retired capacity. This leaves $67.7 \mathrm{GW}$ of generation that elected to fuel switch, blend or purchase $\mathrm{SO}_{2}$ emission credits.

To achieve the Phase 2 limits, these utilities need to switch entirely to low-sulfur coal, scrub or search for alternatives like the Rotary Combustor. Switching many of these boilers to low-sulfur sub-bituminous coals requires that they are derated by as much as 10\%-30\% in response to a variety of plant bottlenecks, including mill capacity, boiler furnace heat absorption and ESP particulate control. Blending with high-sulfur eastern bituminous coal will not give compliance with the lower $1.2 \mathrm{lb}$. $\mathrm{SO}_{2} / \mathrm{MM}$ Btu emission limit.

It is estimated that at least $75 \%$ of these units $(50 \mathrm{GW})$ will retrofit equipment to comply with the Phase 2 legislation. The potential market is $\$ 4.5$ billion. In 1996, the Spinheat, Ltd. business plan anticipated capturing $10 \%$ of this market, or roughly $\$ 450$ million for a 10 -year period between 1996 and 2006.

A core market of 110 units that are individually less than $300 \mathrm{MW}$ is identified from this population. These units are particularly suitable for the Rotary Combustor because of the existing burner size and configuration. This population represents a total market potential of $\$ 2.5$ billion, or a $\$ 250$ million for the Rotary Combustor, assuming the Spinheat, Ltd. objective of $10 \%$ market penetration.

In Ohio, there are 29 units that meet the twofold criteria of requiring retrofit emissions control equipment and producing less than $300 \mathrm{MW}$ each. These units generate roughly 5,250 MW. They constitute approximately one-quarter of the units in the United States that 
meet the above criteria. This generation requires 10.5 million tons of coal annually, assuming a $65 \%$ unit capacity factor. If the Rotary Combustor is demonstrated as a viable technology for refiring these generators while burning Ohio high-sulfur coal, and Spinheat achieves its market penetration objective of $10 \%$, the market for Spinheat, Ltd. is roughly $\$ 47$ million dollars, and the market for Ohio coal in these units is approximately 1 to 2 million tons per year.

In 2000, the Rotary Combustor likely will require a specialized application in the industrial boiler market for initial penetration.

While $\mathrm{SO}_{2}$ allowances remained between $\$ 96 /$ ton and $\$ 210 /$ ton in $1998, \mathrm{NO}_{\mathrm{x}}$ allowance costs increased from \$1425/ton to \$3500/ton between 1997 and 1998 .

\subsection{Final Budget Summation}

The two tables on the following page provide a budget summary for the Rotary Combustor Demonstration Project.

The first table shows that the actual expenditures were over the project budget by $\$ 5,730$. This amount constitutes about $1.3 \%$ of the total budget. The OCDO and U. S. DoE contributions were exactly on the budget. CONSOL and Spinheat jointly assumed a higher cost share.

The second table compares the project budget to actual OCDO expenditures, and gives a balance by major category. Total OCDO expenditures were on budget. Deviations from the budget by major category are summarized as follows: Labor expenditures exceed the budgeted amount by $\$ 9,024$ or $12.8 \%$, Travel expenditures are $\$ 2,838$ or $42 \%$ less than the budgeted amount, Materials and Supplies expenditures are $\$ 3,616$ or $16.8 \%$ below the budgeted amount, and Contractual expenditures are actually $\$ 0$ compared to the budgeted amount of $\$ 2,400$. Total Direct expenditures exceed the budget by $\$ 170$ or $1.7 \%$, leaving Indirect expenditures $\$ 170$ below budget to balance the overall project budget. 


\begin{tabular}{||l|r|r|r|r|r||}
\hline \multicolumn{7}{|c|}{ Total Project Budget by Major Category and Contributions of Co-sponsors } \\
\hline \multicolumn{1}{|c|}{ Budget Category } & Actual Expenditures & \multicolumn{1}{c|}{ OCDO } & \multicolumn{1}{c|}{ CONSOL } & \multicolumn{1}{c|}{ Spinheat } & \multicolumn{1}{c|}{ U. S. DoE } \\
\hline Labor & $\$ 190,373$ & $\$ 62,385$ & $\$ 40,291$ & $\$ 25,312$ & $\$ 62,385$ \\
\hline Fringe Benefits & $\$ 51,913$ & $\$ 17,151$ & $\$ 10,652$ & $\$ 6,959$ & $\$ 17,151$ \\
\hline Travel & $\$ 12,201$ & $\$ 3,829$ & $\$ 2,989$ & $\$ 1,554$ & $\$ 3,829$ \\
\hline Material \& Supplies & $\$ 53,203$ & $\$ 17,931$ & $\$ 10,066$ & $\$ 7,275$ & $\$ 17,931$ \\
\hline Other Direct & $\$ 645$ & $-0-$ & $\$ 645$ & $-0-$ & $-0-1$ \\
\hline Indirect & $\$ 126,500$ & $\$ 41,739$ & $\$ 26,087$ & $\$ 16,935$ & $\$ 41,739$ \\
\hline Total & $\$ 434,835$ & $\$ 143,035$ & $\$ 90,730$ & $\$ 58,035$ & $\$ 143,035$ \\
\hline
\end{tabular}

OCDO - Ohio Coal Development Office

CONSOL - CONSOL Energy Inc.

Spinheat - Spinheat, Ltd.

U. S. DoE - United States Department of Energy, National Energy Technology Laboratory (NETL)

\begin{tabular}{||l|r|r|r||}
\hline \multicolumn{4}{|c|}{ OCDO Expenditures by Major Category } \\
\hline \multicolumn{1}{|c|}{ Budget Category } & Total Project Budget & OCDO Expenditures & \multicolumn{1}{c||}{ Balance } \\
\hline Labor & $\$ 70,511$ & $\$ 79,535$ & $(\$ 9,024)$ \\
\hline Fringe Benefits & $-0-$ & $-0-$ & $-0-$ \\
\hline Travel & $\$ 6,667$ & $\$ 3,829$ & $\$ 2,838$ \\
\hline Equipment & $-0-$ & $-0-$ & $-0-$ \\
\hline Material \& Supplies & $\$ 21,547$ & $\$ 17,931$ & $\$ 3,616$ \\
\hline Contractual & $\$ 2,400$ & $-0-$ & $\$ 2,400$ \\
\hline Total Direct Charges & $\$ 101,125$ & $\$ 101,295$ & $(\$ 170)$ \\
\hline Indirect & $\$ 41,910$ & $\$ 41,739$ & $\$ 170$ \\
\hline Total & $\$ 143,035$ & $\$ 143,035$ & $-0-$ \\
\hline
\end{tabular}


$\underline{\text { Appendices }}$

Appendix A

Appendix B

Operating Manual for the Rotary Combustor New or Revised Fabrication Drawings 
Appendix A: Operating Manual for the Rotary Combustor

General Description

Mechanical Design and Construction

Standard Operating Procedures

Emergency Procedures

Operating Hazards

Operator Responsibilities

Waste Disposal

Procedure for Modification 


\section{Appendix B: New or Revised Fabrication Drawings}

Drawing Number
P1-01/R12
DOE3-1001/R3
DOE3-05/R10
DOE3-1001/R4
DOE3-1002/R0
P1-02/5/R0
P1-02/4/R0
DOE3-1001/R5
P1-02/4/R1
P1-02/5/R1
P1-05/3R0
DOE3-1001/R6
P1-05/3R1
DOE3-1003/R0
DOE3-1004/R0

\author{
Description \\ Rotary Combustor General Arrangement Drawing \\ Ash Trough Assembly Drawing \\ Firetube \\ Ash Trough Assembly \\ Weir Plate \& Weir Skirt \\ Brush Seal Land Ring \\ Brush Seal Rings \\ Ash Trough Assembly \\ Brush Seal Rings \\ Brush Seal Land Ring \\ Ignitor Details \& UV Tube \\ Ash Trough Assembly \\ Ignitor Details \& UV Tube \\ Composite RGC Distributor Plate \\ Coal Distribution Vanes
}

Date
$06 / 30 / 98$
$06 / 17 / 98$
$06 / 22 / 98$
$07 / 09 / 98$
$07 / 08 / 98$
$07 / 21 / 98$
$06 / 28 / 98$
$07 / 29 / 98$
$07 / 30 / 98$
$07 / 30 / 98$
$08 / 10 / 98$
$08 / 17 / 98$
$09 / 02 / 98$
$09 / 15 / 98$
$10 / 19 / 98$ 